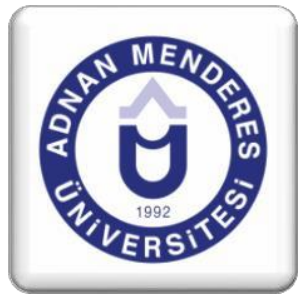

\title{
Drama Temelli Dijital Hikâye Anlatıcılığı Programının 6 Yaş Çocuklarının Bazı Sosyal Becerilerinin Gelişimine Etkisi ${ }^{1}$
}

\author{
Fazilet BAŞDAŞ ${ }^{2}$, Ruken AKAR VURAL ${ }^{3}$
}

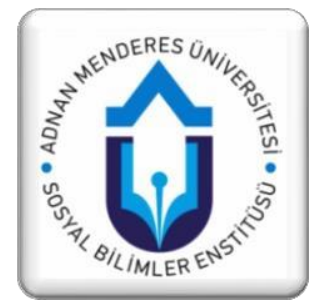

\section{Özet}

$\mathrm{Bu}$ araştırma, ana sınıfına devam eden altı yaş çocuklarının, bazı sosyal becerilerine drama temelli dijital hikâye anlatıcılığı programının etkisini belirlemek amacıyla yapılan yarı deneysel bir çalışmadır. Araştırma 2016 - 2017 eğitim öğretim yılının birinci yarıyılında Aydın ili Efeler ilçesindeki resmi bir anaokulunda yapılmıştır. Araştırma bir deney ve bir kontrol grubunda bulunan toplam 48 çocuk üzerinde gerçekleştirilmiştir. On hafta süren araştırmada deney grubuna drama temelli dijital hikâye anlatıcılığı programında yer alan etkinlikler uygulanırken, kontrol grubunda okul öncesi programında yer alan etkinlikler kendi öğretmenleri tarafindan uygulanmıştır. Ölçme aracı olarak deney ve kontrol grubuna "Sosyal Becerileri Değerlendirme Ölçeği” (Avcıŏlu, 2007) öntest - sontest olarak uygulanmıştır. Ayrıca deneysel müdahale programının öncesinde, çocuklar hakkında bilgi edinmek amacıyla "Kişisel Bilgi Formu" kullanılmışıı. Araştırmada veri toplama araçlarından elde edilen verilerin çözümleri SPSS (23.0) paket programından yararlanılarak gerçekleştirilmiştir. Grupların Sosyal Becerileri Değerlendirme Ölçeğinden aldıkları puanlar arasında farklılaşma olup olmadığını belirlemek için kovaryans analizi kullanılmışır. Analizlerde anlamlılık düzeyi $\mathrm{p}<.05$ olarak alınmıștır. Sonuç olarak Sosyal Beceriler Değerlendirme Ölçeğinden elde edilen sontest puanları açısından deney ve kontrol grupları arasında deney grubu lehine anlamlı fark bulunmuştur. Ölçeğin dokuz alt boyutundan "Kızgınlık Davranışlarını Kontrol Etme ve Değişikliklere Uyum Sağlama Becerileri”, "Akran Baskısı ile Basa Çıkma Becerileri”, "Sözel Açıklama Becerileri”, "Dinleme Becerileri”, "Amaç Oluşturma Becerileri" ve "Görevleri Tamamlama Becerileri" alt boyutlarında deney grubu lehine anlamlı fark bulunmuştur. "Kişiler Arası Beceriler", "Kendini Kontrol Etme Becerileri” ve "Sonuçları Kabul Etme Becerileri” alt boyutlarında ise deney ve kontrol grubu sontest puanları açısından anlamlı bir fark bulunamamıştır.

Anahtar Kelimeler: Dijital hikâye, eğitimde drama, sosyal beceriler, sosyal becerileri değerlendirme ölçeği.

\section{The Effects Of Drama Based Digital Storytelling Program To 6 Age Childrens' Some Social Skills}

\begin{abstract}
In this quasi experimental study, the effects of drama based digital storytelling program to 6 age childrens' some social skills were investigated. The study was conducted at a public pre-school in the district of Efeler-Aydin in 2016-2017 academic year. The participants of the study were 48 students that were divided into an experimental group and a control group. In the study which lasted 10 weeks, activities in the drama based "Digital Storytelling" program were used in experimental group and activities in the pre-school curriculum were used in the control group. The measurement instrument "Social Skills Assessment Scale"(Avcıŏlu, 2007) was given as a pre-test and posttest. In the beginning of the research, "Personal Information Form" was given to find out the characteristics of the experimental group and control group. In the study, the data obtained by"Social Skills Assessment Scale" was operated by statistics computer program SPSS 23.0. Covariance analysis was used to find out if there was a meaningful difference. The level of significance was $p<.05$. As a result, meaningful differences were observed in favor of the experimental group in terms of total points obtained from the Social Skills Assessment Scale. There was a significant difference in favor of the experimental group in terms of "Controlling the anger behaviour and the abilities of adapting to changes","Coping with the peer pressure","Verbal description skills","Listening skills", "Creating aim skills"and"Completing the tasks skills" sub-scales scores. There was no significant difference among experimental and control groups in terms of "Interpersonal Skills","Self-Control Skills" and "Skills to Accept Results" sub-scales scores.
\end{abstract}

Keywords: Digital storytelling, drama in education, social skills, social skills assessment scale.

\footnotetext{
${ }^{1} \mathrm{Bu}$ çalışma Adnan Menderes Üniversitesi, Sosyal Bilimler Enstitüsü’ne 2017 yılında sunulan "Drama Temelli Dijital Hikâye Anlatıcılığı Programının 6 Yaş Çocuklarının Bazı Sosyal Becerilerinin Gelişimine Etkisi” adlı yüksek lisans tezinden derlenmiştir.

${ }^{2}$ Milli Eğitim Bakanlığı, Biliş̧im Teknolojileri Öğretmeni, faziletbasdas@gmail.com

${ }^{3}$ Doç.Dr., Adnan Menderes Üniversitesi, Eğitim Fakültesi, Eğitim Bilimleri Bölümü, rakarvural@ gmail.com
} 


\section{Giriş}

Öğrenme ve öğretme ile ilgili tarihsel sürece bakıldığında, süreçte yaşanan gelişmelerle yaklaşımların, stratejilerin, araç - gereçlerin, yöntem ve tekniklerin zamanla evrildiği görülmektedir. Teknolojinin hızla gelişmesi, materyallerin daha ucuz ve kolay ulaşılabilir duruma gelmesi, okullarda teknolojik donanımın çeşit ve sayı bakımından artırılmasına önem veren eğitim politikalarıyla, eğitim ortamlarının teknoloji ile birleşmesi kaçınılmaz olmuştur (Yang ve $\mathrm{Wu}, 2012$ ).

Kotluk ve Kocakaya (2015)'nın çalışmasında yer alan farklı kurum ve kuruluşlar (Partnership for 21st century skills - P21, EnGauge, Assessment and Teaching of 21st Century Skills ATCS, National Educational Technology Standards - NETS/ISTE, EU, OECD) tarafindan 21. yüzyıl becerileri olarak belirtilen ortak beceriler; iletişim, bilgi - medya - teknoloji (ICT) okuryazarlığı, işbirliği ve sosyal kültürel yeterliklerdir. Bunların yanında eleştirel düşünme, problem çözme, problem kurma, yaratıcılık, öz denetim, planlama becerileri de bu kuruluşlar tarafından 21. yüzyıl becerileri kapsamında gösterilmiştir. Eğitim bireylerde bu becerileri kazandırmalıdır. Eğitim programları bu becerileri kazandırma amacına uygun geliştirilmeli, sinıflardaki etkinlikler bu amaca hizmet etmeli, bu becerileri destekleyen öğrenci merkezli yöntem ve teknikler uygulanmalıdır. İlgili alanyazın incelendiğinde bu becerileri kazandırmaya yardımcı olduğu görülen dijital hikâye anlatıcılığı da bir araç olarak karşımıza çıkmaktadır.

Hikâyeler, kolay hatırlanabilir özelliği sayesinde öğrenme sürecinde etkili bir araç olarak kullanılabilir (Yüzer ve Kılınç, 2015). Çocukların kendini ifade edebilmesinde, dil gelişiminde, sosyal ortama alışmasında, problem çözme becerisinin ve yaratıcılığının gelişmesinde hikâye etkili ve önemli bir yere sahiptir (Akca, Aytan ve Ünlü, 2016). Hikâyeler, çocukların hayal gücünü geliştirmelerinin yanında bilgileri somutlaştırıp basitleştirerek gerçek hayatı algılamalarına yardımcı olmaktadır (Turgut ve Kışla, 2005). Çağın gereksinimleriyle zamanla değişen hikâye anlatıcılığı dijital ortama aktarılıp anlatılmaya başlanmıştır. Dijital hikâye anlatımı metin, ses, resim, video ve müziği dijital ortamda sunma sürecidir (Figa, 2004). Farklı ülkelerde çok uzak mesafelerde olan bireyler, internetin avantajlarından yararlanarak kendi deneyimlerini aktarmak için dijital hikâyeleri kullanmaktadırlar. Eğitimciler de dijital hikâyeciliğin önemini keşfederek eğitimle ilgili faaliyetlerde araç olarak kullanmışlardır (İnceelli, 2005).

Robin (2008)'e göre dijital hikâye anlatıcılığı, sınıflarda teknolojinin daha verimli kullanılmasını ve çocukların içerikten daha fazla yararlanabilmelerini sağlayabilecek teknolojik bir uygulamadır. Ayrıca bu uygulama çocukların öğrenme - öğretme sürecine daha aktif bir şekilde katılmasına yardımcı olarak öğrenci merkezli öğrenmenin teşvik edilmesini sağlamaktadır. (Xu, Park \& Baek, 2011). Birden çok duyu organına hitap eden bir ortam sunduğu için öğrenmenin kalıcı hale getirilmesini desteklemektedir (Turgut ve Kışla, 2015). Diğer taraftan dijital hikâye anlatıcılığı, çocukların teknolojiyi yaratıcı biçimde kullanmalarını ve bu yolla "kendi anlamlarını" oluşturabilmelerini sağlamaktadır (Flewitt, Messer ve Kucirkova, 2014; Haggerty, 2011).

Hızla gelişim ve değişim yaşanan günümüzde bireylerle kolay iletişim kurabilen, kurduğu ilişkileri sürdürebilen, düşüncelerini ifade etmekte zorlanmayan, sosyal becerileri bakımından gelişmiş bireylere ihtiyaç artmaktadır. Sosyal beceriler, farklı etkileşimler içinde kişinin kendisinin ve etrafındaki kişilerin davranış, duygu ve düşüncelerini anlaması ve bu anlayışla tutarlı tepkiler gösterebilmesidir (Çubukçu ve Gültekin, 2006). Sosyal becerilerin çoğu aile 
içinde veya akran gruplarıyla farkına varılmadan edinilmektedir. Çocuklar genelde sosyal öğrenme kuramında da olduğu gibi model alarak gözlem yoluyla sosyal becerileri öğrenmektedirler. Ancak çocukların sosyal becerileri informal biçimde edinirken desteklenmesi de gerekmektedir. Bazı becerileri çocuklara sistemli olarak öğretmek ve becerileri kullanırken yardımcı olmak gerekmektedir (Avcıoğlu, 2007). Hayatın ilk yıllarından itibaren desteklenmesi gereken sosyal becerilen kazandırılmasında ebeveynlerin ve öğretmenlerin önemli bir yeri bulunmaktadır. Kuşkusuz çocuklar, okul öncesi eğitimde kullanılan etkinlik ve yöntemler yardımıyla sosyal becerileri kazanabilir (Ceylan, 2009).

Sosyal beceriler, diğer alanların yanında akademik başarı için de ön koşullardan biridir. Gelişim alanlarının birbirini etkilemesi ve gelişimin bir bütün olması ilkeleri sosyal becerilerle ilgili çalışmaları desteklemektedir. Bu sebeple bireylerin sağlıklı, başarılı ve mutlu olmaları hedefleniyorsa çocukluktan itibaren sosyal beceriler eğitimine gereken önem verilmelidir (Erbay, 2008). Çocukların kendini rahat bir şekilde ifade edebilmesi, özgüven kazanabilmeleri, etrafındakilerle sağlıklı ilişkiler kurabilmeleri gibi becerilerin gelişmesi için öğretmenlerin uygun öğrenme - öğretme çevreleri oluşturması, bu becerileri kazandırmada etkili olacaktır.

Sosyal beceri eğitiminde kullanılabilecek yöntemlerden bazıları rol oynama, model olma, gösteri, doğrudan öğretim, akran destekli öğrenme, drama ve işbirlikli öğrenmedir. Çocuklarda sosyal becerileri geliştirmek için eğitimde dramanın önemli bir yeri vardır. Eğitimde drama yöntemi, öğreneni her öğretim hedefine ulaştırmayabilir ancak pek çok hedefe ulaştırmada etkili ve keyifli bir yoldur (Akar Vural ve Somers, 2016). Diğer taraftan öğrencinin fiziksel olarak sınıfta olması öğrenmeyi garantileyemez. Aynı zamanda öğrenci bilişsel ve duyuşsal olarak da katılım sağlamalıdır. Dramada 1sınma çalışmalarının temel amacı da budur. Isınma çalışmaları öğreneni güdüleyerek öğrenmeye hazırlar (Akar, 2000). Çocukların empati kurabilmesini, kendilerini tanıyıp ifade edebilmelerini sağlayan drama, yaparak yaşayarak öğrenme kavramı açısından da en etkili yöntemlerdendir (Avcıŏglu, 2012).

Drama ile ilgili etkinlikler birbirlerini dinleme, hem duyguları hem de düşünceleri ifade edebilme, problem çözebilme ve işbirliği yapabilme, esnek ve yaratıcı düşünebilme, özdenetim, güven duyabilme, saygı ve sevgi duyma, başkalarının ve kendilerinin duygudüşüncelerini keşfetme, farkındalık, kendisinin ve başkalarının davranışlarının nedenini anlayabilme, kurallara uyup sorumluluk alabilme gibi sosyal becerilerinin gelişmesine katkı sağlamaktadır (Büyüköztürk vd, 2014). Drama çalışmaları bireylerin çeşitli rollere girerek çeşitli durum ve olaylarla ilgili deneyim kazanması, bireylerde araştırma isteğini geliştirme, yaşamın farklı yönlerden algılanmasını sağlama, kalıcı öğrenme gibi kazanımlar sağlayarak bireylerin gelişiminde önemli bir yere sahip olur (Köksal Akyol, 2003).

Ezberin kenara bırakıldığı, çocukların duygularını, düşüncelerini, tutumlarını, deneyimlerini, isteklerini, bilgilerini öne çıkararak grup içinde etkileşim halinde, paylaşarak ve gözlemleyerek öğrenme ortamı sunan uygulamaları ön plana çıkaran drama, okul öncesi dönemde de geniş bir yer tutmaktadır (Ulutaş, 2011). Bu anlamda "eğitimde drama" ve "dijital hikâye"nin okul öncesi dönemdeki çocukların gelişim sürecine uygun, keyifli ve etkili yöntemlerden olduğu söylenebilir. Ancak ilgili alanyazın incelendiğinde bu iki kavramın okul öncesi dönemde beraber kullanıldığı ve ortak etkisine bakıldığı bir çalışmaya rastlanmamıştır. Bu nedenle bu çalışmada, eğitimde drama temelli dijital hikâye anlatıcılığ 1 programının anasınıfına devam eden altı yaş çocuklarının bazı sosyal becerilerinin (kişiler arası beceriler, akran baskısı ile başa çıkma becerileri, sözel açılama becerileri vb.) gelişimine etkisi incelenmiştir. 


\subsection{Dijital Hikâye}

Eski çağlardan günümüze kadar hikâye anlatımı çeşitli ortamlarda ve şekillerde kullanılmıştır. Teknolojinin ve internetin yaygınlaşmasıyla dijital ortama aktarılarak da kullanılmaya başlanmıştır (Sadik,2008). Dijital hikâye anlatıcılığı geleneksel hikâye anlatıcılığının resim, müzik, ses ve video gibi dijital içeriklerle harmanlanmasıyla oluşmuştur. Geleneksel hikâyelerle verilmek istenen mesaj, ses ve müziğin katkısıyla daha etkili bir şekilde karşı tarafa iletilebilmektedir (Tatl, 2016).

Dijital hikâye anlatımı metin, ses, resim, video ve müziği dijital ortamda sunma sürecidir. Yazarları güçlendiren ve hikâye anlatımı kavramına yeni anlamlar kazandıran etkileşimli süreçle diğer hikâyelerle değiştirilebilecek, birleştirilebilecek bir firsat sunmaktadır (Figa,2004). Genellikle iki-üç dakika uzunlukta olan dijital hikâyeler kişisel konuları ve tarihsel olayları anlatma, belirli bir konuyla ilgili bilgi verme, motive etme, gösteri gibi çeşitli amaçlarla kullanılmaktadır (Robin,2006; Robin, 2008). Wang ve Zhan(2010)'a göre dijital hikâye anlatımı, geleneksel hikâye anlatımını modern yaklaşımla sunmaktır. Ayrıca dijital hikâyeler, farklı branşlardan öğretmenlerin çeşitli yaşlara, kültüre, eğitim durumuna sahip öğrenciler için kullanabileceği bir araçtır (Garcia ve Rossiter, 2010).

Dijital hikâye anlatıcılığı sayesinde geleneksel hikâye anlatıcılığıyla gerçekleştirilenlere ek olarak birçok nitelik eğitim ortamlarına gelmiştir. Çocuklar dijital hikâye oluşturma sürecinde daha aktif rol alırlar, kendi özelliklerinin farkına varırlar ve teknolojiyi daha etkili kullanabilirler. Sadik tarafindan 2008 yılında yapılan bir araştırmada, dijital hikâyeciliğin çocukları bilgilerini ve düşüncelerini ifade etmelerinde cesaretlendirdiği görülmüştür. Ayrıca Robin (2008), hikâyelerin paylaşılmasıyla çocukların kendilerini ve başkalarını eleştirebileceğini ifade etmiş, bu durumun da çocuklarda sosyal öğrenme ve duygusal zekâlarının gelişiminde faydalı olacağını belirtmiştir.

Dijital hikaye anlatıcısı, hayal gücünü kullanarak mümkün olduğunca esnek ve birçok duyuya hitap edebilen bir dijital ortamda özgürce hikayesini canlandırabilmektedir. Bu imkanlarla öğrenmenin daha kalıcı hale getirilmesi de desteklenmiş olmaktadır (Turgut ve Kışla, 2015). Bunun yanında kişilere kendilerini daha rahat ifade edebilecekleri ortam sağlanmakta, çağımızın gerektirdiği şekilde teknolojik donanımları kullanan, bilgiyi üreten, yapılandıran, sorgulayıcı bireyler yetişmesinde rol oynamaktadır. Süreci kendileri yönlendirdiği için kişileri aktif hale getirerek, problem çözmeye teşvik etmekte ve bilgilerin pekişmesine, gerçek hayatta uygulanabilmesine olanak tanımaktadır (Ayvaz Tunç ve Karadağ, 2013). Karakoyun (2014) yaptı̆̆ çalışmada, sınıfta dijital hikâye kullanımıyla benlik, kimlik ve aidiyet kavramlarında olumlu etki gözlemlemiş, çocukların kendisini daha rahat ifade ettiklerini belirtmiştir.

\subsubsection{Dijital Hikâyenin Ögeleri}

Lambert (2010)'a göre etkili bir dijital hikâye oluşturmak için yedi ögeye dikkat etmek gerekmektedir. Bu ögeler: Dikkat çekici soru, bakış açısı, duygusal içerik, ses, müziğin gücü, hız ayarı, ekonomi (Lambert, 2010; Karakoyun, 2014; Tatlı, 2016). Ögeler açıklamalarıyla birlikte Tablo 1'de verilmiştir. 
Tablo 1. Dijital hikâyenin ögeleri

\begin{tabular}{ll}
\hline Ögeler & Açıklamalar \\
\hline 1.Dikkat Çekici Soru & Hikâye anlatımı süresince cevabı merak edilen soru \\
\hline 2.Bakış Açısı & Hikâyenin teması ve yazarın bakış açısı \\
\hline 3.Duygusal İçerik & İçeriğin, hikâye ve izleyiciler arasında duygusal bağ kurması \\
\hline 4.Ses & Hikâyenin anlaşılması ve kişiselleştirilmesi amacıyla hikâyeyi seslendirme \\
\hline 5.Müziğin Gücü & Hikâyeyle uyumlu ve hikâyeyi destekleyici fon müzik kullanılması \\
\hline 6.Hız ayarı & Hikâyenin hızlı veya yavaş ilerleyeceğinin belirlenmesi (hikâyenin ritmi) \\
\hline 7.Ekonomi & $\begin{array}{l}\text { İzleyicilerde aşırı bilgi yüklemesine engel olmak için içeriğin sade olması bilgi, bilgi } \\
\text { kalabalığından uzak olması }\end{array}$ \\
\hline
\end{tabular}

\subsubsection{Dijital Hikâye Oluşturma Süreci}

Dijital hikâyenin etkili ve amacina uygun olması için hikâye oluşturma süreci doğru planlanmalıdır. $\mathrm{Bu}$ sürecin aşamalarıyla ilgili alanyazında farklı adımlar bulunmaktadır. Örneğin Jakes ve Brennan (2005), bu süreci yazım, senaryo, hikâye panosu, çoklu ortam ögelerinin araştırılması, dijital hikâyenin oluşturulması ve paylaşım olmak üzere altı adımda toplamışlardır. Kearney (2011) üretim öncesi, üretim, üretim sonrası ve dağıtım başlıklarında bu süreci ele almıştır (Tatlı, 2016). Barrett (2009) ise bu sürecin adımlarını senaryo geliştirme, ses kaydı, resim bulma ve düzenlemeleri, sesleri ve görüntüleri birleştirme, arka plan müziği, başlıklar, geçişler ekleme ve hikâyenin bitmiş halini yayınlama olarak belirtmiştir. Araştırmacıların geliştirdiği hikâye oluşturma süreçlerinin genellikle hikâye senaryosu oluşturma ile başlayıp hikâyenin paylaşılmasıyla sona erdiği görülmektedir. Bu aşamalardan yola çıkılarak dijital hikâye oluşturma süreci Tablo 2'de verilen adımlarda toplanmıştır.

Tablo 2. Dijital hikâye oluşturma süreci

1. Senaryonun Oluşturulması

2. Hikâye Panosunun Oluşturulması

3. Resimlerin Programa Eklenmesi

4. Ses Kaydı Yapılması

5. Dijital Hikâyenin Düzenlenmesi

6. Paylaşım

\subsection{Eğitimde Drama}

Eğitimde drama, herhangi bir konunun dramayla işlenmesini ifade eden ve dramanın öğretim yöntemi olarak ele alınan şeklidir. Sanat formları ve teknikleri kullanmakla beraber esas amaç katılımcilara kurgusal mekânda, gerçek deneyimlerin rol oynama ve yaparak yaşayarak kazandırılmasıyla yeni öğrenmelerin oluşturulmasıdır (Akar Vural, 2005). 
Eğitimde drama kavramını McCaslin (2006) eğitimde dramanın temel amaçlarını yaratıcılık ve estetik bakışın gelişmesi, takımla çalışma ve iletişim becerilerinin gelişimi, eleştirel düşünmenin gelişimi, bireyin kendisinin farkına varması, diğer kültürleri tanıması şeklinde belirtmiştir.

Oyun, çocuk gelişimi bakımından önemli bir gerekliliktir. Eğitimde drama çalışmaları da oyunlara benzer şekilde, çocuklarda merak, ilgi, araştırma, inceleme ve keşfetme duygusu oluşturduğu için mutluluk duymalarını sağlamaktadır. Çocuklar dramada kullanılan çeşitli tekniklerle örneğin doğaçlamayla, dramatik dilde ve temsilde gittikçe konuya daha yatkın olacaklardır. Bunun için de öğretmen, çocukları desteklemeli, sorularıyla daha fazla düşünmelerini sağlamalıdır (Akar Vural ve Somers, 2016). Drama, katılımcıların fiziksel, duygusal, zihinsel gelişimleri üzerinde olumlu etkiler meydana getirdiğinden eğitimin önemli bir parçası olarak görülmüştür (Sağlam, 2014).

Eğitimde dramada kullanılan tekniklerle ilgili alanyazın tarandığında farklı tekniklerle karşılaşılmaktadır. Daha sık kullanılan teknikler şunlardır: Donuk imge, dans drama, ses takibi, fotoğraf karesi, düşünce takibi, doğaçlama, sıcak sandalye, aradaki boşluk, bilinç koridoru, forum tiyatro, buzdağı, rol içinde yazma, toplantı düzenleme, dedikodu halkası, öğretmenin role girmesi, koro halinde konuşma, geriye dönüş, kâğıt üzerinde karakter oluşturma, tamamlanmamış materyaller, bir başkasının role girmesi.

\subsection{Sosyal Beceri}

Sosyal beceri, sosyal kabulü olan, eksikliğinde olumsuz sonuçlar meydana gelebilen, gözlenebilen ve öğrenilen davranışlardır (Erbay, 2008). Sosyal yeterlilik ve sosyal beceri kavramı sıkça karıştırılan kavramlardandır. Sosyal yeterlilik, vücut dilini kullanma, yorumlama, o anki durumla ilgili konuşma, tartışma gibi sözel ve sözel olmayan davranışları barındırır. Bu davranışların doğru kullanılması, bireylerin sosyal yeterlilikleri belirler. Sosyal beceri, sosyal yeterlilik kavramına göre daha dar kapsamdadır. Sosyal beceri, bireyin başkalarıyla etkileşimlerini olumlu yönde başlatması ve sürdürmesi, sorumluluk alması, problem çözmeye yönelik becerileri, grupla uyum içinde çalışması, stresle başa çıkması, kendini kontrol edebilme becerisi, saldırganlıkla başa çıkma becerisi gibi ifadelerle ele alınmaktadır (Akfırat Önalan, 2006). Toplumun kabul ettiği sosyal davranışların sergilenmesi yeteneğini sosyal yeterlilik kavramı kapsarken, belirli bir sosyal ortamdaki sergilenen davranış biçimini sosyal beceri kavramı karşılar (Erbay, 2008).

Bireyler, sosyal beceriler sayesinde başka bireylerle ilişkilerinde daha sağlkklı iletişsim kurabilir, bireylerin duygu ve haklarına saygılı olabilir, kendisine göre uygun bulmadığı istekleri reddedebilir, başkalarıyla uyum içinde işbirliği yapabilir veya yardım isteyebilir (Özyürek ve Ceylan, 2014).

Sosyal becerilerin çoğu aile içinde veya akran gruplarıyla farkına varılmadan öğrenilmektedir. Çocuklar genelde sosyal öğrenme kuramında da olduğu gibi model alarak gözlem yoluyla sosyal becerileri öğrenmektedirler. Ancak her zaman çocuklardan sosyal becerileri plansız, eğitime gerek duymadan öğrenmelerini bekleyemeyiz. Bazı becerileri çocuklara sistemli olarak öğretmek ve becerileri kullanırken desteklemek gerekmektedir (Avcıŏglu, 2007). Hayatın ilk yıllarından itibaren desteklenmesi gereken sosyal becerilen kazandırılmasında ebeveynlerin ve öğretmenlerin önemli bir yeri bulunmaktadır. Okul öncesi eğitimde kullanılan etkinlik ve yöntemler yardımıyla çocuklar sosyal becerileri kazanabilir (Ceylan, 2009). 
Sosyal beceriler, diğer alanların yanında akademik başarı için de ön koşuldur. Gelişim alanlarının birbirini etkilemesi ve gelişimin bir bütün olması ilkeleri sosyal becerilerle ilgili çalışmaları desteklemektedir. $\mathrm{Bu}$ sebeple bireylerin sağlıklı, başarılı ve mutlu olmaları hedefleniyorsa çocukluktan itibaren sosyal beceriler eğitimine gereken önem verilmelidir (Erbay, 2008).

\subsubsection{Okul Öncesi Dönemde Sosyal Beceriler}

Okul öncesi dönemi, gelişimin epey hızlı olduğu bir dönemdir. Literatüre bakıldığında 0-6 yaş dönemindeki kazanılan davranışların daha sonraki dönemlerde de sürdüğü, kişilik yapısını, alışkanlıkları ahlak yapısını etkilediğini ve temelini oluşturduğu görülmüştür (Tuğluk vd, 2008). Bu dönemdeki yaşantıların ilerleyen senelerdeki yaşamı da etkileyebileceğinden bu dönemdeki eğitim ciddi olarak ele alınarak tesadüflere bırakılmamalıdır. Çocuğun gelecek yaşantısını önemli derecede etkileyebilecek olan sosyal becerilerin kazanımı da dikkatle ele alınmalıdır (Göktaş, 2015).

Beş, altı yaşındaki çocuklardan paylaşmaları, yardım etmeleri, kural ve yönergelere uymaları, güven duymaları, işbirliğiyle çalışmaları, bağımsız çalışabilmeleri, sınıflarında bir gruba girebilmeleri, arkadaş edinebilmeleri, öfkelerini kontrol edebilmeleri, oyunlarını oluşturup belirli kurallar koyabilmeleri, arkadaşlarının duygularını paylaşabilmeleri beklenmektedir. Bunun yanında rekabetle birlikte paylaşım, işbirliği, dayanışma gibi davranışlar da beklenmektedir (Ceylan, 2009).

Çocukların sosyal becerileri öğrenmelerinde etkileyici rol oynayan birçok faktör vardır. Bunlardan bazıları aile içindeki etkileşim, sınıfın ve okulun sosyal ortamı, akranlar arasındaki etkileşim, bireysel özelliklerdir. Örneğin okul öncesi dönemde akranları tarafından dışlanan ve akran baskısına maruz kalan bir çocukta ilerleyen yıllarda depresyon, kaygı ve yalnızlık gibi durumların görülmesinde okul öncesi dönem yaşantılarının etkili olduğu ileri sürülmektedir (Büyüköztürk vd, 2014). Bilek (2011)' e göre ise bu faktörler yaş, okul, cinsiyet, engelli olup olmama, akran ilişkisi ve okuldur. Çocuğun etrafindaki en etkili kişilerden olan aile bireyler ve öğretmenler çocuğun gelişimine uygun etkinlikler yardımıyla sosyal becerilerin kazanılmasında destek sağlamalıdırlar. Sosyal beceri eğitiminde kullanılabilecek yöntemlerden rol oynama, model olma, gösteri, doğrudan öğretim, akran destekli öğrenme, drama ve işbirlikli öğrenme gibi örnekler verilebilir.

Çocuklarda sosyal becerileri geliştirmek için eğitimde dramanın önemli bir yeri vardır. Drama ile ilgili etkinliklerde birbirlerini dinleme, hem duyguları hem de düşünceleri ifade edebilme, problem çözebilme ve işbirliği yapabilme gibi kazanımlar sağlanabilmektedir. Ayrıca çocukların sabırlı olması, esnek ve yaratıcı düşünebilmeleri, özdenetim, güven duyabilme, saygı ve sevgi duyma, başkalarının ve kendilerinin duygu-düşüncelerini keşfetme, farkındalık, kendisinin ve başkalarının davranışlarının nedenini anlayabilme, kurallara uyup sorumluluk alabilme gibi sosyal becerilerinin de gelişmesine katkı sağlamaktadır (Büyüköztürk vd, 2014).

Drama, çocukların oyunlarla öğrenmesini sağlarken eğlenceli bir ortam oluşmasını sağlar. Çocukların empati kurabilmesini, kendilerini tanıyıp ifade edebilmelerini sağlayan drama, yaparak yaşayarak öğrenme kavramı açısından da en etkili yöntemlerdendir (Gönen ve Dalkı1ıç, 2002; akt. Avcıoğlu, 2012). 


\section{Araştırmanın Amacı}

Araştırmanın temel amacı anasınıfına devam eden altı yaş çocukların, bazı sosyal becerilerine drama temelli dijital hikâyeciliğin etkisini belirlemektir. Bu temel amaç doğrultusunda aşağıdaki sorulara yanıt aranmaktadır:

1. Deney ve kontrol grubundaki çocukların "Sosyal Becerileri Değerlendirme Ölçeği (SBDÖ)"nden aldıkları toplam öntest puanları kontrol altına alındığında, sontest puanları arasında deney grubu lehine anlamlı bir fark var midır?

2. Deney ve kontrol grubundaki çocukların SBDÖ "Kişiler Arası Beceriler" alt ölçeğinden aldıkları öntest puanları kontrol altına alındığında, sontest puanları arasında deney grubu lehine anlamlı bir fark var midır?

3. Deney ve kontrol grubundaki çocukların SBDÖ "Kızgınlık Davranışlarını Kontrol Etme ve Değişikliklere Uyum Sağlama Becerileri" alt ölçeğinden aldıkları öntest puanları kontrol altına alındığında, sontest puanları arasında deney grubu lehine anlamlı bir fark var mıdır?

4. Deney ve kontrol grubundaki çocukların SBDÖ "Akran Baskısı ile Basa Çıkma Becerileri” alt ölçeğinden aldıkları öntest puanları kontrol altına alındığında, sontest puanları arasında deney grubu lehine anlamlı bir fark var midır?

5. Deney ve kontrol grubundaki çocukların SBDÖ "Kendini Kontrol Etme Becerileri" alt ölçeğinden aldıkları öntest puanları kontrol altına alındığında, sontest puanları arasında deney grubu lehine anlamlı bir fark var midır?

6. Deney ve kontrol grubundaki çocukların SBDÖ "Sözel Açıklama Becerileri” alt ölçeğinden aldıkları öntest puanları kontrol altına alındığında, sontest puanları arasında deney grubu lehine anlamlı bir fark var midır?

7. Deney ve kontrol grubundaki çocukların SBDÖ "Sonuçları Kabul Etme Becerileri” alt ölçeğinden aldıkları öntest puanları kontrol altına alındığında, sontest puanları arasında deney grubu lehine anlamlı bir fark var midır?

8. Deney ve kontrol grubundaki çocukların SBDÖ "Dinleme Becerileri" alt ölçeğinden aldıkları öntest puanları kontrol altına alındığında, sontest puanları arasında deney grubu lehine anlamlı bir fark var midır?

9. Deney ve kontrol grubundaki çocukların SBDÖ “Amaç Oluşturma Becerileri” alt ölçeğinden aldıkları öntest puanları kontrol altına alındığında, sontest puanları arasında deney grubu lehine anlamlı bir fark var midır?

10.Deney ve kontrol grubundaki çocukların SBDÖ "Görevleri Tamamlama Becerileri” alt ölçeğinden aldıkları öntest puanları kontrol altına alındığında, sontest puanları arasında deney grubu lehine anlamlı bir fark var midır?

\section{Yöntem}

$\mathrm{Bu}$ başlıkta araştırma modeli, çalışma grubu, veri toplama araçları, veri toplama süreci ve verilerin analizi alt başlıkları yer almaktadır.

\subsection{Araștırma Modeli}

Araştırmada anasınıfına devam eden altı yaş çocukların, bazı sosyal becerilerine drama temelli dijital hikâyeciliğin etkisi incelenmiştir. Araştırma "Drama temelli dijital hikâye anlatıcıllı̆ı programı" nın uygulandığı yarı deneysel (quasi - experimental) bir çalışmadır. Kerlinger (1973)'in de belirttiği gibi, eğitim kurumlarında yürütülen araştırmalarda tam random atama 
yapmanın düşük bir olasılığa sahip olması sebebiyle araştırma modeli, yarı deneysel olarak desenlenmiştir.

Aydın ili Efeler ilçesi Milli Eğitim Müdürlüğü'nden izin alınarak bağımsız ve resmi bir anaokulunda deney ve kontrol grubu olarak iki sınıf belirlenmiştir. Araştırmada öntest-sontest kontrol gruplu deneme modeli kullanılmıştır. Deneysel işlemler başlamadan önce ve deneysel işlemler biter bitmez hem deney grubuna hem kontrol grubuna "Sosyal Becerileri Değerlendirme Ölçeği”" verilmiştir. Araştırmada kullanılan modelin simgesel görünümü Tablo 3 'te verilmiştir.

Tablo 3. Deneme modelinin simgesel görünümü

\begin{tabular}{llll}
\hline $\mathbf{G}_{\mathbf{1}}$ & $\mathrm{O}_{1.1}$ & $\mathbf{X}$ & $\mathrm{O}_{1.2}$ \\
\hline $\mathbf{G}_{\mathbf{2}}$ & $\mathrm{O}_{2.1}$ & & $\mathrm{O}_{2.2}$ \\
\hline
\end{tabular}

$\mathbf{G}_{\mathbf{1}}$ : Deney Grubu

$\mathbf{G}_{2}$ : Kontrol Grubu

X: Deneysel müdahale (Drama temelli dijital hikâye anlatıcılığı programı)

$\mathbf{O}_{1.1^{-}} \mathbf{O}_{2.1}$ : Öntest Puanları

$\mathbf{O}_{1.2}-\mathbf{O}_{2.2}:$ Sontest Puanlar1

\section{2. Çalışma Grubu}

$\mathrm{Bu}$ araştırma 2016-2017 eğitim - öğretim yılı birinci yarıyılında Aydın ili Efeler ilçesinde bulunan resmi bir anaokulunda altı yaşında, sosyoekonomik düzeyleri birbirine yakın olan yirmi dörder çocuğun bulunduğu deney ve kontrol grubu olmak üzere iki grupta gerçekleştirilmiştir. Çalışma grubu belirlenirken alınan izinlerle okullarla görüşülmüş, gerekli teknolojik donanıma sahip okuldan gönüllü öğretmen ve çocuğun olduğu, benzer sosyalekonomik özelliklere sahip, aynı yaşta ve eğitim-öğretim süreci dışında birbirleriyle etkileşimi oldukça sınırlı olan çocukların bulunduğu iki sınıf seçilmiştir. Çocuklar hakkında anne ve baba mesleği, cinsiyet, yaş soruları ele alınarak deneysel işleme başlamadan bilgiler toplanmıştır. Araştırmaya katılan çocukların cinsiyet değişkenine göre dağılımı Tablo 4'te verilmiştir.

Tablo 4. Araştırmaya katılan çocukların cinsiyet değişkenine göre dağılımı

\begin{tabular}{llll}
\hline & Kiz & Erkek & Toplam \\
\hline Deney Grubu & 13 & 11 & 24 \\
\hline Kontrol Grubu & 11 & 13 & 24 \\
\hline
\end{tabular}

Çocukların "baba mesleği” değişkenine göre dağılımı Tablo 5'te verilmiştir. Bu tabloya göre deney ve kontrol grubunun baba mesleği açısından benzer olduğu görülmektedir. 
Tablo 5. Deney ve kontrol gruplarındaki çocukların baba mesleği değişkenine göre dağılımı

\begin{tabular}{lllllll}
\hline & \multicolumn{2}{c}{ Gruplar } & & & \\
& \multicolumn{2}{c}{ Deney Grubu } & Kontrol Grubu & Toplam & \\
\hline Baba Mesleği & f & $\%$ & F & \% & f & \% \\
\hline Serbest Meslek & 3 & 12.5 & 1 & 4.2 & 4 & 8.3 \\
\hline Memur & 9 & 37.5 & 6 & 25 & 15 & 31.3 \\
\hline Emekli & 1 & 4.2 & 0 & 0.0 & 1 & 2.1 \\
\hline İşçi & 11 & 45.8 & 11 & 45.8 & 22 & 45.8 \\
\hline Özel Sektör & 0 & 0.0 & 6 & 25 & 6 & 12.5 \\
\hline Çalışmiyor & 0 & 0.0 & 0 & 0.0 & 0 & 0.0 \\
\hline Toplam & 24 & 100.0 & 24 & 100.0 & 48 & 100.0 \\
\hline
\end{tabular}

Çocukların "anne mesleği” değişkenine göre dağılımı Tablo 6'da verilmiştir. Bu tabloya göre deney ve kontrol grubunun anne mesleği açısından benzer olduğu görülmektedir.

Tablo 6. Deney ve kontrol gruplarındaki çocukların anne mesleği değişkenine göre dağılımı

\begin{tabular}{|c|c|c|c|c|c|c|}
\hline \multirow[b]{3}{*}{ Anne Mesleği } & \multicolumn{6}{|c|}{ Gruplar } \\
\hline & \multicolumn{2}{|c|}{ Deney Grubu } & \multicolumn{2}{|c|}{ Kontrol Grubu } & \multicolumn{2}{|c|}{ Toplam } \\
\hline & f & $\%$ & $\mathbf{F}$ & $\%$ & f & $\%$ \\
\hline Serbest Meslek & 0 & 0.0 & 0 & 0.0 & 0 & 0.0 \\
\hline Memur & 5 & 20.8 & 5 & 20.8 & 10 & 20.8 \\
\hline Emekli & 0 & 0.0 & 0 & 0.0 & 0 & 0.0 \\
\hline İşçi & 0 & 0.0 & 2 & 8.3 & 2 & 4.2 \\
\hline Özel Sektör & 0 & 0.0 & 1 & 4.2 & 1 & 2.1 \\
\hline Çalışmıyor & 19 & 79.2 & 16 & 66.7 & 35 & 72.9 \\
\hline Toplam & 24 & 100.0 & 24 & 100.0 & 48 & 100.0 \\
\hline
\end{tabular}

\subsection{Veri Toplama Araçları}

Bu araştırmada veri toplama aracı olarak "Kişisel Bilgi Formu" ve Avcıoğlu (2007)'nun geliştirdiği "Sosyal Becerileri Değerlendirme Ölçeği (4-6 Yaş)" kullanılmıştır. "Kişisel Bilgi Formu" uygulamaya başlamadan önce verilmiş olup ailelerden alınan bilgilerle deney grubu ve kontrol grubunun öğretmenleri tarafindan doldurulmuştur. "Sosyal Becerileri Değerlendirme Ölçeği (4-6 Yaş)" ise uygulamadan önce öntest olarak, uygulamadan sonra sontest olarak kullanılmış ve çocukların yaşı nedeniyle kendileri kullanamayacağından öğretmenleri aracılığıyla veriler toplanmıştır. 


\subsubsection{Kişisel Bilgi Formu}

Araştırmacı tarafindan çocuklar hakkında bilgi almak için hazırlanmış olan bu formda cinsiyet, yaş, anne ve baba mesleği ifadeleri yer almaktadır. Bu veri toplama aracı deney ve kontrol gruplarının öğretmenlerine uygulamadan önce verilmiş, aileler ve okul idaresi yardımıyla bilgiler toplanmıştır.

\subsubsection{Sosyal Becerileri Değerlendirme Ölçeği}

Avcıoğlu (2007) tarafından geliştirilen bu ölçek dokuz alt boyuttan ve toplam 62 maddeden oluşmaktadır. Tamamı olumlu yönde ve her zaman yapar (5), çok sık yapar(4), genellikle yapar(3), çok az yapar(2), hiçbir zaman yapmaz(1) seçeneklerinin yer aldığı maddelerle beşli likert tipinde geliştirilen bir ölçme aracıdır. Hem alt boyutlardan alınan puana göre hem toplam puana göre değerlendirme yapılabilmektedir. Ölçme aracından hesaplanan puan yüksekse sosyal becerilere sahip olunduğunu belirtmektedir.

Avcıoğlu tarafından gerçekleştirilen, ölçeğin güvenirliğinin ve geçerliğinin belirlenmesi için yapılan çalışmada 52 okulöncesi öğretmeni kendi sınıflarındaki 251 öğrenci adına ölçek doldurmuştur. Testi yarılama yöntemi ve tüm öğrenciler arasından rastgele seçilen 150 öğrenciyle test-tekrar test yöntemi kullanılmıştır. Ölçeğin tamamından elde edilen Cronbach Alpha değeri .89' dur. Ölçeğin dokuz alt boyutundan alınan değerler ise kişiler arası beceriler için .95, kızgınlık davranışlarını kontrol etme ve değişikliklere uyum sağlama becerileri için .94 , akran baskısı ile başa çıkma becerileri için .92, kendini kontrol etme becerileri için .91, sözel açıklama becerileri için .85, sonuçları kabul etme becerileri için .95 , dinleme becerileri için .87 , amaç oluşturma becerileri için .78 ve görevleri tamamlama becerileri için .88 'dir (Avcioğlu, 2007).

Araştırmacı tarafından yapılan çalışmada ölçeğin güvenirliğinin belirlenmesi için, iki okul öncesi öğretmeninin kendi sınıflarındaki 48 çocuk adına doldurduğu ölçekten elde edilen verilerle Cronbach Alpha değerleri hesaplanmıştır. Ölçeğin tamamından elde edilen Cronbach Alpha değeri .98' dir. Ölçeğin dokuz alt boyutundan alınan değerler ise kişiler arası beceriler için .97, kızgınlık davranışlarını kontrol etme ve değişikliklere uyum sağlama becerileri için .92, akran baskısı ile başa çıkma becerileri için .97, kendini kontrol etme becerileri için .78, sözel açıklama becerileri için .93, sonuçları kabul etme becerileri için .96, dinleme becerileri için .98 , amaç oluşturma becerileri için .98 ve görevleri tamamlama becerileri için .98 'dir.

\subsection{Veri Toplama Süreci}

Araştırma için Aydın İl Milli Eğitim Müdürlügü̈nden gerekli izinler alındıktan sonra uygulama aşamasında geçilmiş̧ir. Uygulama 2016-2017 eğitim - öğretim yılı birinci döneminde Aydın ili Efeler ilçesindeki bağımsız ve resmi bir anaokulunda öğrenim görmekte olan altı yaşındaki 48 çocuk ile on haftalık bir süreç boyunca gerçekleşmiştir.

Deneysel sürece geçilmeden deney grubu ve kontrol grubundaki çocuklara "Sosyal Becerileri Değerlendirme Ölçeği” öntest olarak uygulanmıştır. Daha sonra deney grubuna haftada üç ders saati olmak üzere drama temelli hikâye anlatıcılığı programı uygulanmıştır. Program, okul 
öncesi dönem çocuklarının hedef sosyal becerilerini destekleyeceği düşünülen "Çirkin Ördek Yavrusu" masalının drama teknikleri yoluyla grup yaşantılarına dayalı olarak işlenmesi ve masalların çocukların yorumu ile dijital ortama aktarılması sürecini kapsamaktadır. Kontrol grubuna ise kendi öğretmenleri tarafından okul öncesi programındaki etkinlikler uygulanmıştır.

Deneysel süreç tamamlandıktan sonra deney ve kontrol gruplarındaki çocuklara "Sosyal Becerileri Değerlendirme Ölçeği" sontest olarak uygulanmıştır. Öntest ve sontest sonuçlarından elde edilen verilerle istatistiksel işlemler yapılarak araştırma sorularına yanıt aranmıştır.

\subsubsection{Deneysel İşlemler}

Deney grubundaki çocuklarla kendi öğretmenleri tarafindan ilk iki hafta etkinliklerinde drama yöntemine hazırlık için isınma egzersizleri yapılmıştır. Kontrol grubuna ise süreç boyunca kendi öğretmenleri tarafından okul öncesi programındaki etkinlikler uygulanmıştır.

Isınma egzersizlerinden sonra haftada üç ders saati olmak üzere drama temelli dijital hikâye anlatıcılığı programı uygulanmıştır. Bu programda Çirkin Ördek Yavrusu masalı çeşitli drama teknikleri(doğaçlama, donuk imge, koro halinde konuşma vb.) kullanılarak işlenmiştir. Örneğin; masaldaki anne ördeğin yumurtaların çatlamasını beklemesi, yumurtaların çatlaması, çirkin ördek yavrusunun yumurtadan en son çıkması, annenin farklı yavruyu görünce hissettikleri çocuklarla gruplar halinde ve doğaçlama tekniği kullanılarak işlenmiştir. Daha sonra çocuklardan yapılan doğaçlamalarla ilgili resim yapmaları istenmiştir. Dijital hikâyenin oluşabilmesi için uygulamanın diğer planlanan aşamalarında da çocuklardan kendi yorumlarıyla resim yapmaları istenmiştir. Resimler tamamlandıktan sonra seslendirme aşamasına geçilmiştir. Çirkin ördek yavrusunu, annesini, kardeşini, çocuğu seslendirecek ve masalı anlatacak çocuklar seçildikten sonra okulda sessiz bir ortamda metnin cümleleri tek tek öğretmen tarafindan okunmuş, çocuklar tarafindan tekrar edilmiştir. Araştırmacı tarafından cep telefonu ile ses kaydı yapılırken gerekli görülen yerler tekrarlanmış, metindeki duyguyu izleyicilere aktarabilmek için vurgu ve tonlamalara dikkat edilmiştir. Daha sonra araştırmacı, ücretsiz olarak indirilip kullanılabilen Audacity programıyla ses kayıtlarındaki gürültüleri giderme, ses tonlarını ayarlama gibi düzenlemeler yapmıştır.

Hazırlanan görsellerle ve ses kayıtlarıyla dijital hikâye oluşturmak için ücretsiz ve kullanımı kolay bir program olan Windows Movie Maker programı seçilmiştir. Çocuklara program tanıtıldıktan sonra görseller ve ses dosyaları programın içine araştırmacının yardımıyla çocuklar tarafından aktarılmıştır. Sahne geçişleri ve çeşitli efektler eklendikten sonra arka plan müziği de eklenmiştir. Çocukların uygulama sırasında birbirlerinin farklılıkları ve bunların iyi yanları üzerine düşünüp grupça tartışarak belirledikleri ögütler, dijital hikâyede son kısma ilave edilmiştir. Başlık ve hazırlayanların isimleri de eklenince son düzenlemeler yapılarak paylaşıma hazır hale getirilmiştir. Sınıfça hazırlanan dijital hikâye izlenmiş ve değerlendirilmiştir. Daha sonra okul müdürü tarafindan izlenen videonun internet ortamında paylaşılması için izin alınmıştır. İzinler tamamlandıktan sonra internet ortamında paylaşılan çalışmanın okulun web sayfasına yüklenmesiyle veliler, öğretmenler ve çocukların her ortamda çalışmaya ulaşması sağlanmıştır (https://youtu.be/1Gheo1klb6U). 


\subsection{Verilerin Analizi}

Deney ve kontrol gruplarından uygulama öncesinde ve uygulama sonrasinda elde edilen verilerin analizi için SPSS 23. 0 istatistik programı kullanılmıştır. Grupların öntest puanları açısından istatistiksel olarak anlamlı bir farklılık gösterip göstermediğini belirlemek amacıyla bağımsız örneklem t-testi analizi kullanılmışıı. Grupların sontest puanları arasında anlamlı farklılık olup olmadığını belirlemek için kovaryans analizi kullanılmış ve öntest puanları kontrol altına alınmıştır.

Kovaryans analiziyle öntest - sontest kontrol gruplu araştırma modellerinde, uygulamanın (işlemin) etkisine odaklanıldığında öntestin ortak olan etkisi kontrol altına alınarak, sadece uygulamanın etkisine ulaşılmaya çalışılabilir (Büyüköztürk, 2005).

Elde edilen analiz edilmiş verilerle yorum yapmak için anlamlılık düzeyi .05 olarak kabul edilmiştir.

\section{Bulgular}

Bu bölümde elde edilen bulgular, araştırmanın alt problemleri doğrultusunda verilmiştir.

\subsection{Birinci Alt Probleme İlişkin Bulgular}

Araştırmanın birinci alt problemi şu şekildedir:

"Deney ve kontrol grubundaki çocukların 'Sosyal Becerileri Değerlendirme Ölçeği (SBDÖ)'nden aldıkları toplam öntest puanları kontrol altına alındığında, sontest puanları arasında deney grubu lehine anlamlı bir fark var midir?"

Deney ve kontrol grubundaki çocukların "Sosyal Becerileri Değerlendirme Ölçeği”nden elde edilen öntest-sontest puanlarının aritmetik ortalama, standart sapma değerleri ile kovaryans analizi sonucunda elde edilen düzeltilmiş sontest puan ortalamaları ile standart hata değerleri Tablo 8'de verilmiştir.

Tablo 8. Deney grubu ve kontrol grubundaki çocukların SBDÖ'den elde edilen öntest-sontest puanlarının standart sapma, aritmetik ortalama değerleri, sontest düzeltilmiş puan ortalamaları ve standart hata değerleri

\begin{tabular}{|c|c|c|c|c|c|c|c|}
\hline \multirow[t]{2}{*}{ Gruplar } & \multicolumn{4}{|c|}{ Toplam Puanlar } & \multirow{2}{*}{$\begin{array}{c}\begin{array}{c}\text { Düzeltilmiş } \\
\text { Ortalamaları }\end{array} \\
\overline{\boldsymbol{X}}_{\boldsymbol{d}}\end{array}$} & \multirow{2}{*}{$\begin{array}{l}\text { Sontest } \\
\text { Sh } \\
\end{array}$} & \multirow[t]{2}{*}{ Puan } \\
\hline & $\mathbf{N}$ & & $\bar{X}$ & SS & & & \\
\hline \multirow[t]{2}{*}{ Deney Grubu } & \multirow{2}{*}{24} & Öntest & 176.00 & 19.75 & & & \\
\hline & & Sontest & 244.79 & 26.39 & 250.50 & 4.15 & \\
\hline \multirow{2}{*}{$\begin{array}{l}\text { Kontrol } \\
\text { Grubu }\end{array}$} & \multirow{2}{*}{24} & Öntest & 187.88 & 25.25 & & & \\
\hline & & Sontest & 225.50 & 32.15 & 219.80 & 4.15 & \\
\hline
\end{tabular}

Tablo 8'deki verilere bakıldığında hem deney grubunun hem kontrol grubunun SBDÖ sontest puan ortalamalarının, öntest puan ortalamalarından yüksek olduğu görülmektedir. Deney grubunun ortalaması $(\bar{X}=250.50)$, kontrol grubu ortalamasına $(\bar{X}=219.80)$ göre daha yüksek 
çıkmışıı. İki grubun ortalamaları arasındaki bu farkın anlamlı olup olmadığını görmek için kovaryans analizi yapılmış, bulunan sonuçlar Tablo 9'da gösterilmiştir.

Tablo 9. Deney ve kontrol grubundaki çocukların SBDÖ sontest toplam puanlarının kovaryans analizi sonuçları

\begin{tabular}{|c|c|c|c|c|c|c|}
\hline Varyansın Kaynağı & $\begin{array}{l}\text { Kareler } \\
(\mathrm{KT})\end{array}$ & Toplamı & $\mathrm{Sd}$ & Kareler Ortalaması (KO) & $\mathrm{F}$ & $\mathrm{P}$ \\
\hline $\begin{array}{l}\text { Kontrol Edilen } \\
\text { Değişken (Öntest) }\end{array}$ & 21797.46 & & 1 & 21797.46 & 54.52 & .00 \\
\hline Gruplama Ana Etkisi & 10551.60 & & 1 & 10551.60 & 26.40 & .00 \\
\hline Hata & 17992.50 & & 45 & 399.83 & & \\
\hline Toplam & 2698347.00 & & 48 & & & \\
\hline
\end{tabular}

Tablo 9'daki kovaryans analiz sonuçları incelendiğinde öntest puanları kontrol altına alındığında, grupların düzeltilmiş sontest puan ortalamaları yönünden uygulanan drama temelli dijital hikâye anlatıcılığı programının anlamlı bir farklılaşma $(F=26.40 ; p=.00)$ oluşturduğu görülmüştür. Deney grubunun ortalamasının $(\bar{X}=250.50)$, kontrol grubunun ortalamasından $(\bar{X}=219.80)$ daha yüksek çıkması ve $\mathrm{p}<.05$ olması deney grubu lehine anlamlı farklılık olduğunu göstermektedir.

\section{2. İkinci Alt Probleme İlişkin Bulgular}

Araştırmanın ikinci alt problemi şu şekildedir:

"Deney ve kontrol grubundaki çocukların SBDÖ "Kişiler Arası Beceriler" alt ölçeğinden aldıkları öntest puanları kontrol altına alındığında, sontest puanları arasında deney grubu lehine anlamlı bir fark var midır?"

Deney ve kontrol grubundaki çocukların SBDÖ “Kişiler Arası Beceriler (KB)" alt ölçeğinden elde edilen öntest - sontest puanlarının aritmetik ortalama, standart sapma değerleri ile kovaryans analizi sonucunda elde edilen düzeltilmiş sontest puan ortalamaları ile standart hata değerleri Tablo 10'da verilmiştir.

Tablo 10. Deney ve kontrol grubundaki çocukların KB'den elde edilen öntest-sontest puanlarının aritmetik ortalama, standart sapma, sontest düzeltilmiş puan ortalamaları ve standart hata değerleri

\begin{tabular}{|c|c|c|c|c|c|c|c|}
\hline \multirow{2}{*}{ Gruplar } & \multicolumn{4}{|c|}{ Toplam Puanlar } & \multirow{2}{*}{$\begin{array}{c}\begin{array}{c}\text { Düzeltilmiş } \\
\text { Ortalamaları }\end{array} \\
\qquad \overline{\boldsymbol{X}}_{\boldsymbol{d}}\end{array}$} & \multirow{2}{*}{$\begin{array}{l}\text { Sontest } \\
\text { Sh } \\
\end{array}$} & \multirow[t]{2}{*}{ Puan } \\
\hline & $\mathbf{N}$ & & $\bar{X}$ & SS & & & \\
\hline \multirow[t]{2}{*}{ Deney Grubu } & \multirow{2}{*}{24} & Öntest & 43.67 & 4.15 & & & \\
\hline & & Sontest & 58.13 & 9.62 & 59.70 & 1.82 & \\
\hline \multirow{2}{*}{$\begin{array}{l}\text { Kontrol } \\
\text { Grubu }\end{array}$} & \multirow{2}{*}{24} & Öntest & 48.08 & 9.19 & & & \\
\hline & & Sontest & 58.30 & 10.35 & 56.72 & 1.82 & \\
\hline
\end{tabular}

Tablo 10'daki verilere bakıldığında hem deney grubunun hem kontrol grubunun KB sontest puan ortalamalarının, öntest puan ortalamalarından yüksek olduğu görülmektedir. Deney 
grubunun ortalamas1 $(\bar{X}=59.70)$, kontrol grubu ortalamasina $(\bar{X}=56.72)$ göre daha yüksek çıkmıştır. İki grubun ortalamaları arasındaki bu farkın anlamlı olup olmadığını görmek için kovaryans analizi yapılmış, bulunan sonuçlar Tablo 11'de gösterilmiştir.

Tablo 11. Deney ve kontrol grubundaki çocukların KB sontest puanlarının kovaryans analizi sonuçları

\begin{tabular}{|c|c|c|c|c|c|c|}
\hline Varyansın Kaynağı & $\begin{array}{l}\text { Kareler } \\
(\mathrm{KT})\end{array}$ & Toplamı & $\mathrm{Sd}$ & Kareler Ortalaması (KO) & $\mathrm{F}$ & $\mathrm{P}$ \\
\hline $\begin{array}{l}\text { Kontrol Edilen } \\
\text { Değişken (Öntest) }\end{array}$ & 1188.58 & & 1 & 1188.58 & 15.70 & .00 \\
\hline Gruplama Ana Etkisi & 96.98 & & 1 & 96.98 & 1.28 & .26 \\
\hline Hata & 3407.01 & & 45 & 75.71 & & \\
\hline Toplam & 167230.00 & & 48 & & & \\
\hline
\end{tabular}

Tablo 11'deki kovaryans analiz sonuçları incelendiğinde öntest puanları kontrol altına alındığında, grupların düzeltilmiş sontest puan ortalamaları yönünden anlamlı bir farklılaşma $(\mathrm{F}=1.28 ; \mathrm{p}=.26)$ oluşmadığ görülmüştür. Anlamlı bir farklılık olmamasına rağmen deney grubunun öntest ortalamas1 $(\bar{X}=43.67)$, kontrol grubunun öntest ortalamasindan $(\bar{X}=48.08)$ daha düşükken iki grubun da sontest ortalamaları aynı değerlere (deney grubu $\bar{X}=58.13$, kontrol grubu $\bar{X}=58.30$ ) çıkmıştır.

\section{3. Üçüncü Alt Probleme İlişsin Bulgular}

Araştırmanın üçüncü alt problemi şu şekildedir:

"Deney ve kontrol grubundaki çocukların SBDÖ "Kızgınlık Davranışlarını Kontrol Etme ve Değişikliklere Uyum Sağlama Becerileri” alt ölçeğinden aldıkları öntest puanları kontrol altına alındığında, sontest puanları arasında deney grubu lehine anlamlı bir fark var mıdır?"

Deney ve kontrol grubundaki çocukların SBDÖ "Kızgınlık Davranışlarını Kontrol Etme ve Değişikliklere Uyum Sağlama Becerileri (KDKEDUSB)" alt ölçeğinden elde edilen öntest, sontest puanlarının aritmetik ortalama, standart sapma değerleri ile kovaryans analizi sonucunda elde edilen düzeltilmiş sontest puan ortalamaları ile standart hata değerleri Tablo 12 'de verilmiştir. 
Tablo 12. Deney ve kontrol grubundaki çocukların KDKEDUSB'den elde edilen öntest-sontest puanlarının aritmetik ortalama, standart sapma, sontest düzeltilmiş puan ortalamaları ve standart hata değerleri

\begin{tabular}{|c|c|c|c|c|c|c|c|}
\hline \multirow{2}{*}{ Gruplar } & \multicolumn{4}{|c|}{ Toplam Puanlar } & \multirow{2}{*}{$\begin{array}{l}\begin{array}{l}\text { Düzeltilmiş } \\
\text { Ortalamaları }\end{array} \\
\overline{\boldsymbol{X}}_{\boldsymbol{d}}\end{array}$} & \multirow{2}{*}{$\begin{array}{l}\text { Sontest } \\
\text { Sh } \\
\end{array}$} & \multirow[t]{2}{*}{ Puan } \\
\hline & $\mathbf{N}$ & & $\bar{X}$ & SS & & & \\
\hline \multirow[t]{2}{*}{ Deney Grubu } & \multirow{2}{*}{24} & Öntest & 30.92 & 2.73 & & & \\
\hline & & Sontest & 42.88 & 4.36 & 44.12 & 0.83 & \\
\hline \multirow{2}{*}{$\begin{array}{l}\text { Kontrol } \\
\text { Grubu }\end{array}$} & \multirow{2}{*}{24} & Öntest & 33.71 & 5.30 & & & \\
\hline & & Sontest & 38.29 & 6.34 & 37.04 & 0.83 & \\
\hline
\end{tabular}

Tablo 12'deki verilere bakıldığında hem deney grubunun hem kontrol grubunun KDKEDUSB sontest puan ortalamalarının, öntest puan ortalamalarından yüksek olduğu görülmektedir. Deney grubunun ortalaması $(\bar{X}=44.12)$, kontrol grubu ortalamasına $(\bar{X}=37.04)$ göre daha yüksek çıkmıştır. İki grubun ortalamaları arasındaki bu farkın anlamlı olup olmadığını görmek için kovaryans analizi yapılmış, bulunan sonuçlar Tablo 13' te gösterilmiştir.

Tablo 13. Deney ve kontrol grubu çocuklarının KDKEDUSB sontest puanlarının kovaryans analizi sonuçları

\begin{tabular}{|c|c|c|c|c|c|c|}
\hline Varyansın Kaynağı & $\begin{array}{l}\text { Kareler } \\
(\mathrm{KT})\end{array}$ & Toplamı & $\mathrm{Sd}$ & Kareler Ortalaması (KO) & $\mathrm{F}$ & $\mathrm{P}$ \\
\hline $\begin{array}{l}\text { Kontrol Edilen } \\
\text { Değişken (Öntest) }\end{array}$ & 654.04 & & 1 & 654.04 & 41.48 & .00 \\
\hline Gruplama Ana Etkisi & 539.61 & & 1 & 539.61 & 34.22 & .00 \\
\hline Hata & 709.55 & & 45 & 15.77 & & \\
\hline Toplam & 80672.00 & & 48 & & & \\
\hline
\end{tabular}

Tablo 13'teki kovaryans analiz sonuçları incelendiğinde öntest puanları kontrol altına alındığında, grupların düzeltilmiş sontest puan ortalamaları yönünden anlamlı bir farklılaşma $(\mathrm{F}=34.22 ; \mathrm{p}=.00)$ olduğu görülmüştür. Deney grubunun ortalamasının $(\bar{X}=44.12)$, kontrol grubunun ortalamasından $(\bar{X}=37.04)$ daha yüksek çıkması ve $\mathrm{p}<.05$ olması deney grubu lehine anlamlı farkl11ık olduğunu göstermektedir.

\subsection{Dördüncü Alt Probleme İlişkin Bulgular}

Araştırmanın dördüncü alt problemi şu şekildedir:

"Deney ve kontrol grubundaki çocukların SBDÖ 'Akran Baskısı ile Basa Çıkma Becerileri (ABBCB)'alt ölçeğinden aldıkları öntest puanları kontrol altına alındığında, sontest puanları arasında deney grubu lehine anlamlı bir fark var midır?"

Deney ve kontrol grubundaki çocukların SBDÖ "Akran Baskısı ile Basa Çıkma Becerileri $(\mathrm{ABBCB})$ " alt ölçeğinden elde edilen öntest - sontest puanlarının aritmetik ortalama, standart 
sapma değerleri ile kovaryans analizi sonucunda elde edilen düzeltilmiş sontest puan ortalamaları ile standart hata değerleri Tablo 14'te verilmiştir.

Tablo 14. Deney ve kontrol grubundaki çocukların ABBCB'den elde edilen öntest-sontest puanlarının aritmetik ortalama, standart sapma, sontest düzeltilmiş puan ortalamaları ve standart hata değerleri

\begin{tabular}{|c|c|c|c|c|c|c|c|}
\hline \multirow[t]{2}{*}{ Gruplar } & \multirow[b]{2}{*}{$\mathbf{N}$} & \multicolumn{3}{|c|}{ Toplam Puanlar } & $\begin{array}{l}\text { Düzeltilmiş } \\
\text { Ortalamalar1 }\end{array}$ & Sontest & Puan \\
\hline & & & $\bar{X}$ & SS & $\bar{X}_{d}$ & Sh & \\
\hline \multirow{2}{*}{$\begin{array}{l}\text { Deney } \\
\text { Grubu }\end{array}$} & \multirow{2}{*}{24} & Öntest & 27.17 & 3.78 & & & \\
\hline & & Sontest & 39.67 & 5.20 & 38.42 & 1.13 & \\
\hline \multirow{2}{*}{$\begin{array}{l}\text { Kontrol } \\
\text { Grubu }\end{array}$} & \multirow{2}{*}{24} & Öntest & 21.63 & 7.55 & & & \\
\hline & & Sontest & 27.88 & 6.42 & 29.13 & 1.13 & \\
\hline
\end{tabular}

Tablo 14'teki verilere bakıldığında hem deney grubunun hem kontrol grubunun ABBCB sontest puan ortalamalarının, öntest puan ortalamalarından yüksek olduğu görülmektedir. Deney grubunun ortalaması $(\bar{X}=38.42)$, kontrol grubu ortalamasina $(\bar{X}=29.13)$ göre daha yüksek çıkmıştır. İki grubun ortalamaları arasındaki bu farkın anlamlı olup olmadığını görmek için kovaryans analizi yapılmış, bulunan sonuçlar Tablo 15' te gösterilmiştir.

Tablo 15. Deney ve kontrol grubu çocuklarının ABBCB sontest puanlarının kovaryans analizi sonuçları

\begin{tabular}{|c|c|c|c|c|c|c|c|}
\hline Varyansın Kaynağı & $\begin{array}{l}\text { Kareler } \\
(\mathrm{KT})\end{array}$ & Toplamı & $\mathrm{Sd}$ & $\begin{array}{l}\text { Kareler } \\
(\mathrm{KO})\end{array}$ & Ortalamas1 & $\mathrm{F}$ & $P$ \\
\hline $\begin{array}{l}\text { Kontrol Edilen } \\
\text { Değişken (Öntest) }\end{array}$ & 333.90 & & 1 & 333.90 & & 12.18 & .01 \\
\hline Gruplama Ana Etkisi & 846.07 & & 1 & 846.07 & & 30.85 & .00 \\
\hline Hata & 1234.06 & & 45 & 27.42 & & & \\
\hline Toplam & 57979.00 & & 48 & & & & \\
\hline
\end{tabular}

Tablo 15'teki kovaryans analiz sonuçlanı incelendiğinde öntest puanları kontrol altına alındığında, grupların düzeltilmiş sontest puan ortalamaları açısından anlamlı bir farklılaşma $(\mathrm{F}=30.85 ; \mathrm{p}=.00)$ olduğu görülmüştür. Deney grubunun ortalamasının $(\bar{X}=38.42)$, kontrol grubunun ortalamasından $(\bar{X}=29.13)$ daha yüksek çıkması ve $\mathrm{p}<.05$ olması deney grubu lehine anlamlı farkl111k olduğunu göstermektedir.

\subsection{Beşinci Alt Probleme İlişkin Bulgular}

Araştırmanın beşinci alt problemi şu şekildedir:

"Deney ve kontrol grubundaki çocukların SBDÖ "Kendini Kontrol Etme Becerileri" alt ölçeğinden aldıkları öntest puanları kontrol altına alındığında, sontest puanları arasında deney grubu lehine anlamlı bir fark var mıdır?" 
Deney ve kontrol grubundaki çocukların SBDÖ "Kendini Kontrol Etme Becerileri (KKEB)" alt ölçeğinden elde edilen öntest - sontest puanlarının aritmetik ortalama, standart sapma değerleri ile kovaryans analizi sonucunda elde edilen düzeltilmiş sontest puan ortalamaları ile standart hata değerleri Tablo 16'da verilmiştir.

Tablo 16. Deney ve kontrol grubundaki çocukların KKEB'den elde edilen öntest- sontest puanlarının aritmetik ortalama, standart sapma, sontest düzeltilmiş puan ortalamaları ve standart hata değerleri

\begin{tabular}{|c|c|c|c|c|c|c|c|}
\hline \multirow[t]{2}{*}{ Gruplar } & \multicolumn{4}{|c|}{ Toplam Puanlar } & \multirow{2}{*}{$\begin{array}{c}\begin{array}{c}\text { Düzeltilmiş } \\
\text { Ortalamaları }\end{array} \\
\overline{\boldsymbol{X}}_{\boldsymbol{d}}\end{array}$} & \multirow{2}{*}{$\begin{array}{l}\text { Sontest } \\
\text { Sh } \\
\end{array}$} & \multirow[t]{2}{*}{ Puan } \\
\hline & $\mathbf{N}$ & & $\bar{X}$ & SS & & & \\
\hline \multirow[t]{2}{*}{ Deney Grubu } & \multirow{2}{*}{24} & Öntest & 8.00 & 1.35 & & & \\
\hline & & Sontest & 10.25 & 1.89 & 10.28 & .54 & \\
\hline \multirow{2}{*}{$\begin{array}{l}\text { Kontrol } \\
\text { Grubu }\end{array}$} & \multirow{2}{*}{24} & Öntest & 9.38 & 1.99 & & & \\
\hline & & Sontest & 11.75 & 3.01 & 11.72 & .54 & \\
\hline
\end{tabular}

Tablo 16'daki verilere bakıldığında hem deney grubunun hem kontrol grubunun KKEB sontest puan ortalamalarının, öntest puan ortalamalarından yüksek olduğu görülmektedir. Deney grubunun ortalaması $(\bar{X}=10.28)$, kontrol grubu ortalamasına $(\bar{X}=11.72)$ göre daha düşük çıkmıştır. İki grubun ortalamaları arasındaki bu farkın anlamlı olup olmadığını görmek için kovaryans analizi yapılmış, bulunan sonuçlar Tablo 17'de gösterilmiştir.

Tablo 17. Deney ve kontrol grubundaki çocukların KKEB sontest puanlarının kovaryans analizi sonuçları

\begin{tabular}{lllllll}
\hline Varyansın Kaynağı & $\begin{array}{l}\text { Kareler } \\
(\mathrm{KT})\end{array}$ & Toplamı & $\mathrm{Sd}$ & Kareler Ortalaması (KO) & $\mathrm{F}$ & $\mathrm{P}$ \\
\hline $\begin{array}{l}\text { Kontrol Edilen } \\
\text { Değișken (Öntest) }\end{array}$ & .29 & 1 & .29 & .05 & .83 \\
\hline Gruplama Ana Etkisi & 21.14 & 1 & 21.14 & 3.27 & .08 \\
\hline Hata & 290.71 & 45 & 6.46 & & \\
\hline Toplam & 6126.00 & 48 & & & \\
\hline
\end{tabular}

Tablo 17'deki kovaryans analiz sonuçları incelendiğinde öntest puanları kontrol altına alındığında, grupların düzeltilmiş sontest puan ortalamaları açısından anlamlı bir farklılaşmanın ( $\mathrm{F}=3.27 ; \mathrm{p}=.08)$ oluşmadığı görülmüştür.

\subsection{Altıncı Alt Probleme İlişkin Bulgular}

Araştırmanın altıncı alt problemi şu şekildedir:

"Deney ve kontrol grubundaki çocukların SBDÖ "Sözel Açıklama Becerileri” alt ölçeğinden aldıkları öntest puanları kontrol altına alındığında, sontest puanları arasında deney grubu lehine anlamlı bir fark var midır?" 
Deney ve kontrol grubundaki çocukların SBDÖ "Sözel Açılama Becerileri (SAB)" alt ölçeğinden elde edilen öntest - sontest puanlarının aritmetik ortalama, standart sapma değerleri ile kovaryans analizi sonucunda elde edilen düzeltilmiş sontest puan ortalamaları ile standart hata değerleri Tablo 18' de verilmiştir.

Tablo 18. Deney ve kontrol grubundaki çocukların SAB'den elde edilen öntest- sontest puanlarının aritmetik ortalama, standart sapma, sontest düzeltilmiş puan ortalamaları ve standart hata değerleri

\begin{tabular}{|c|c|c|c|c|c|c|c|}
\hline \multirow[t]{2}{*}{ Gruplar } & \multicolumn{4}{|c|}{ Toplam Puanlar } & \multirow{2}{*}{$\begin{array}{c}\begin{array}{c}\text { Düzeltilmiş } \\
\text { Ortalamaları }\end{array} \\
\overline{\boldsymbol{X}}_{\boldsymbol{d}}\end{array}$} & \multirow{2}{*}{$\begin{array}{l}\text { Sontest } \\
\text { Sh } \\
\end{array}$} & \multirow[t]{2}{*}{ Puan } \\
\hline & $\mathbf{N}$ & & $\overline{\boldsymbol{X}}$ & SS & & & \\
\hline \multirow[t]{2}{*}{ Deney Grubu } & \multirow{2}{*}{24} & Öntest & 18.70 & 3.18 & & & \\
\hline & & Sontest & 26.50 & 3.59 & 27.24 & .67 & \\
\hline \multirow{2}{*}{$\begin{array}{l}\text { Kontrol } \\
\text { Grubu }\end{array}$} & \multirow{2}{*}{24} & Öntest & 20.75 & 4.04 & & & \\
\hline & & Sontest & 25.71 & 4.60 & 24.97 & .67 & \\
\hline
\end{tabular}

Tablo 18'deki verilere bakıldığında hem deney grubunun hem kontrol grubunun SAB sontest puan ortalamalarının, öntest puan ortalamalarından yüksek olduğu görülmektedir. Deney grubunun ortalaması $(\bar{X}=27.24)$, kontrol grubu ortalamasina $(\bar{X}=24.97)$ göre daha yüksek çıkmıştır. İki grubun ortalamaları arasındaki bu farkın anlamlı olup olmadığını görmek için kovaryans analizi yapılmış, bulunan sonuçlar Tablo 19'da gösterilmiştir.

Tablo 19. Deney ve kontrol grubundaki çocukların SAB sontest puanlarının kovaryans analizi sonuçları

\begin{tabular}{|c|c|c|c|c|c|c|c|}
\hline Varyansın Kaynağı & $\begin{array}{l}\text { Kareler } \\
(\mathrm{KT})\end{array}$ & Toplamı & $\mathrm{Sd}$ & $\begin{array}{l}\text { Kareler } \\
(\mathrm{KO})\end{array}$ & Ortalamas1 & $\mathrm{F}$ & $\mathrm{P}$ \\
\hline $\begin{array}{l}\text { Kontrol Edilen } \\
\text { Değişken (Öntest) }\end{array}$ & 321.25 & & 1 & 321.25 & & 31.31 & .00 \\
\hline Gruplama Ana Etkisi & 57.45 & & 1 & 57.45 & & 5.60 & .02 \\
\hline Hata & 461.71 & & 45 & 10.26 & & & \\
\hline Toplam & 33499.00 & & 48 & & & & \\
\hline
\end{tabular}

Tablo 19'daki kovaryans analiz sonuçları incelendiğinde öntest puanları kontrol altına alındığında, grupların düzeltilmiş sontest puan ortalamaları açısından anlamlı farklılık $(\mathrm{F}=$ $5.60 ; \mathrm{p}=.02)$ ortaya çıktığı görülmüştür. Deney grubunun ortalamasının $(\bar{X}=27.24)$, kontrol grubunun ortalamasından $(\bar{X}=24.97)$ daha yüksek çıkması ve $\mathrm{p}<.05$ olması deney grubu lehine anlamlı farklılık olduğunu göstermektedir. 


\subsection{Yedinci Alt Probleme İlişkin Bulgular}

Araştırmanın yedinci alt problemi şu şekildedir:

"Deney ve kontrol grubundaki çocukların SBDÖ "Sonuçları Kabul Etme Becerileri" alt ölçeğinden aldıkları öntest puanları kontrol altına alındığında, sontest puanları arasında deney grubu lehine anlamlı bir fark var mıdır?"

Deney ve kontrol grubundaki çocukların SBDÖ "Sonuçları Kabul Etme Becerileri (SKEB)" alt ölçeğinden elde edilen öntest - sontest puanlarının aritmetik ortalama, standart sapma değerleri ile kovaryans analizi sonucunda elde edilen düzeltilmiş sontest puan ortalamaları ile standart hata değerleri Tablo 20'de verilmiştir.

Tablo 20. Deney ve kontrol grubundaki çocukların SKEB'den elde edilen öntest- sontest puanlarının aritmetik ortalama, standart sapma, sontest düzeltilmiş puan ortalamaları ve standart hata değerleri

\begin{tabular}{|c|c|c|c|c|c|c|c|}
\hline \multirow[t]{2}{*}{ Gruplar } & \multicolumn{4}{|c|}{ Toplam Puanlar } & \multirow{2}{*}{$\begin{array}{c}\begin{array}{l}\text { Düzeltilmiş } \\
\text { Ortalamaları }\end{array} \\
\overline{\boldsymbol{X}}_{\boldsymbol{d}}\end{array}$} & \multirow{2}{*}{$\begin{array}{l}\text { Sontest } \\
\text { Sh } \\
\end{array}$} & \multirow[t]{2}{*}{ Puan } \\
\hline & $\mathbf{N}$ & & $\bar{X}$ & SS & & & \\
\hline \multirow[t]{2}{*}{ Deney Grubu } & \multirow{2}{*}{24} & Öntest & 11.04 & 1.99 & & & \\
\hline & & Sontest & 15.20 & 2.48 & 15.73 & .58 & \\
\hline \multirow{2}{*}{$\begin{array}{l}\text { Kontrol } \\
\text { Grubu }\end{array}$} & \multirow{2}{*}{24} & Öntest & 13.21 & 2.19 & & & \\
\hline & & Sontest & 17.08 & 3.08 & 16.56 & .58 & \\
\hline
\end{tabular}

Tablo 20'deki verilere bakıldığında hem deney grubunun hem kontrol grubunun SKEB sontest puan ortalamalarının, öntest puan ortalamalarından yüksek olduğu görülmektedir. Deney grubunun ortalaması $(\bar{X}=15.73)$, kontrol grubu ortalamasına $(\bar{X}=16.56)$ göre daha düşük çıkmıştır. İki grubun ortalamaları arasındaki bu farkın anlamlı olup olmadığını görmek için kovaryans analizi yapılmış, bulunan sonuçlar Tablo 21'de gösterilmiştir.

Tablo 21. Deney ve kontrol grubundaki çocukların SKEB sontest puanlarının kovaryans analizi sonuçları

\begin{tabular}{|c|c|c|c|c|c|c|}
\hline Varyansın Kaynağı & $\begin{array}{l}\text { Kareler } \\
(\mathrm{KT})\end{array}$ & Toplamı & Sd & Kareler Ortalaması (KO) & $\mathrm{F}$ & $P$ \\
\hline $\begin{array}{l}\text { Kontrol Edilen } \\
\text { Değişken (Öntest) }\end{array}$ & 46.23 & & 1 & 46.23 & 6.63 & .01 \\
\hline Gruplama Ana Etkisi & 6.55 & & 1 & 6.55 & .94 & .34 \\
\hline Hata & 313.56 & & 45 & 6.97 & & \\
\hline Toplam & 12915.00 & & 48 & & & \\
\hline
\end{tabular}

Tablo 21'deki kovaryans analiz sonuçları incelendiğinde öntest puanları kontrol altına alındığında, grupların düzeltilmiş sontest puan ortalamaları bakımından anlamlı bir farklılaşma $(\mathrm{F}=.94 ; \mathrm{p}=.34)$ olmadığı görülmüsstür 


\subsection{Sekizinci Alt Probleme İliş̧kin Bulgular}

Araştırmanın sekizinci alt problemi şu şekildedir:

"Deney ve kontrol grubundaki çocukların SBDÖ “Dinleme Becerileri” alt ölçeğinden aldıkları öntest puanları kontrol altına alındığında, sontest puanları arasında deney grubu lehine anlamlı bir fark var midır?"

Deney ve kontrol grubundaki çocukların SBDÖ "Dinleme Becerileri (DB)" alt ölçeğinden elde edilen öntest - sontest puanlarının aritmetik ortalama, standart sapma değerleri ile kovaryans analizi sonucunda elde edilen düzeltilmiş sontest puan ortalamaları ile standart hata değerleri Tablo 22'de verilmiştir.

Tablo 22. Deney ve kontrol grubundaki çocukların DB'den elde edilen öntest- sontest puanlarının aritmetik ortalama, standart sapma, sontest düzeltilmiş puan ortalamaları ve standart hata değerleri

\begin{tabular}{|c|c|c|c|c|c|c|c|}
\hline \multirow{2}{*}{ Gruplar } & \multicolumn{4}{|c|}{ Toplam Puanlar } & \multirow{2}{*}{$\begin{array}{c}\begin{array}{l}\text { Düzeltilmiş } \\
\text { Ortalamaları }\end{array} \\
\overline{\boldsymbol{X}}_{\boldsymbol{d}}\end{array}$} & \multirow{2}{*}{$\begin{array}{c}\text { Sontest } \\
\text { Sh } \\
\end{array}$} & \multirow[t]{2}{*}{ Puan } \\
\hline & $\mathbf{N}$ & & $\bar{X}$ & SS & & & \\
\hline \multirow{2}{*}{$\begin{array}{l}\text { Deney } \\
\text { Grubu }\end{array}$} & \multirow{2}{*}{24} & Öntest & 16.38 & 2.76 & & & \\
\hline & & Sontest & 23.17 & 2.51 & 23.63 & .51 & \\
\hline \multirow{2}{*}{$\begin{array}{l}\text { Kontrol } \\
\text { Grubu }\end{array}$} & \multirow{2}{*}{24} & Öntest & 18.13 & 3.60 & & & \\
\hline & & Sontest & 21.38 & 3.32 & 20.91 & .51 & \\
\hline
\end{tabular}

Tablo 22'deki verilere bakıldığında hem deney grubunun hem kontrol grubunun DB sontest puan ortalamalarının, öntest puan ortalamalarından yüksek olduğu görülmektedir. Deney grubunun ortalaması $(\bar{X}=23.63)$, kontrol grubu ortalamasına $(\bar{X}=20.91)$ göre daha yüksek çıkmıştır. İki grubun ortalamaları arasındaki bu farkın anlamlı olup olmadığını görmek için kovaryans analizi yapılmış, bulunan sonuçlar Tablo 23' te gösterilmiştir.

Tablo 23. Deney ve kontrol grubundaki çocukların DB sontest puanlarının kovaryans analizi sonuçları

\begin{tabular}{|c|c|c|c|c|c|c|}
\hline Varyansın Kaynağı & $\begin{array}{l}\text { Kareler } \\
(\mathrm{KT})\end{array}$ & Toplamı & $\mathrm{Sd}$ & Kareler Ortalaması (KO) & $\mathrm{F}$ & $\mathrm{P}$ \\
\hline $\begin{array}{l}\text { Kontrol Edilen } \\
\text { Değişken (Öntest) }\end{array}$ & 134.30 & & 1 & 134.30 & 22.84 & .00 \\
\hline Gruplama Ana Etkisi & 82.57 & & 1 & 82.57 & 14.04 & .00 \\
\hline Hata & 264.66 & & 45 & 5.81 & & \\
\hline Toplam & 24245.00 & & 48 & & & \\
\hline
\end{tabular}

Tablo 23'teki kovaryans analiz sonuçlanı incelendiğinde öntest puanları kontrol altına alındığında, grupların düzeltilmiş sontest puan ortalamaları bakımından anlamlı bir farklılaşma $(\mathrm{F}=14.04 ; \mathrm{p}=.00)$ olduğu görülmüştür. Deney grubunun ortalamasının $(\bar{X}=23.63)$, kontrol 
grubunun ortalamasından $(\bar{X}=20.91)$ daha yüksek çıkması ve $\mathrm{p}<.05$ olması deney grubu lehine anlamlı farklılık olduğunu göstermektedir.

\subsection{Dokuzuncu Alt Probleme İlişkin Bulgular}

Araştırmanın dokuzuncu alt problemi şu şekildedir:

"Deney ve kontrol grubundaki çocukların SBDÖ "Amaç Oluşturma Becerileri” alt ölçeğinden aldıkları öntest puanları kontrol altına alındığında, sontest puanları arasında deney grubu lehine anlamlı bir fark var midır?"

Deney ve kontrol grubundaki çocukların SBDÖ "Amaç Oluşturma Becerileri (AOB)" alt ölçeğinden elde edilen öntest - sontest puanlarının aritmetik ortalama, standart sapma değerleri ile kovaryans analizi sonucunda elde edilen düzeltilmiş sontest puan ortalamaları ile standart hata değerleri Tablo 24' te verilmiştir.

Tablo 24. Deney ve kontrol grubundaki çocukların AOB'den elde edilen öntest- sontest puanlarının aritmetik ortalama, standart sapma, sontest düzeltilmiş puan ortalamaları ve standart hata değerleri

\begin{tabular}{|c|c|c|c|c|c|c|c|}
\hline \multirow[t]{2}{*}{ Gruplar } & \multicolumn{4}{|c|}{ Toplam Puanlar } & \multirow{2}{*}{$\begin{array}{c}\begin{array}{l}\text { Düzeltilmiş } \\
\text { Ortalamaları }\end{array} \\
\overline{\boldsymbol{X}}_{\boldsymbol{d}}\end{array}$} & \multirow{2}{*}{$\begin{array}{c}\text { Sontest } \\
\text { Sh } \\
\end{array}$} & \multirow[t]{2}{*}{ Puan } \\
\hline & $\mathbf{N}$ & & $\bar{X}$ & SS & & & \\
\hline \multirow{2}{*}{$\begin{array}{l}\text { Deney } \\
\text { Grubu }\end{array}$} & \multirow{2}{*}{24} & Öntest & 9.67 & 1.90 & & & \\
\hline & & Sontest & 14.63 & 1.01 & 14.93 & .31 & \\
\hline \multirow{2}{*}{$\begin{array}{l}\text { Kontrol } \\
\text { Grubu }\end{array}$} & \multirow{2}{*}{24} & Öntest & 10.88 & 2.35 & & & \\
\hline & & Sontest & 11.63 & 2.39 & 11.32 & .31 & \\
\hline
\end{tabular}

Tablo 24'teki verilere bakıldığında hem deney grubunun hem kontrol grubunun AOB sontest puan ortalamalarının, öntest puan ortalamalarından yüksek olduğu görülmektedir. Deney grubunun ortalaması $(\bar{X}=14.93)$, kontrol grubu ortalamasına $(\bar{X}=11.32)$ göre daha yüksek çıkmıştır. İki grubun ortalamaları arasındaki bu farkın anlamlı olup olmadığını görmek için kovaryans analizi yapılmış, bulunan sonuçlar Tablo $25^{\prime}$ 'te gösterilmiştir.

Tablo 25. Deney ve kontrol grubundaki çocukların AOB sontest puanlarının kovaryans analizi sonuçları

\begin{tabular}{lllllll}
\hline Varyansın Kaynağı & $\begin{array}{l}\text { Kareler } \\
(\mathrm{KT})\end{array}$ & Toplamı & $\mathrm{Sd}$ & $\begin{array}{l}\text { Kareler } \\
(\mathrm{KO})\end{array}$ & Ortalaması & $\mathrm{F}$ \\
\hline $\begin{array}{l}\text { Kontrol Edilen } \\
\text { Değişken (Öntest) }\end{array}$ & 54.40 & 1 & 54.40 & 24.28 & .00 \\
\hline Gruplama Ana Etkisi & 144.75 & 1 & 144.75 & 64.59 & .00 \\
\hline Hata & 100.85 & 45 & 2.24 & & \\
\hline Toplam & 8532.00 & 48 & & & \\
\hline
\end{tabular}


Tablo 25'teki kovaryans analiz sonuçları incelendiğinde öntest puanları kontrol altına alındığında, grupların düzeltilmiş sontest puan ortalamaları bakımından anlamlı bir farklılaşma $(\mathrm{F}=64.59 ; \mathrm{p}=.00)$ oluştuğu görülmüştür. Deney grubunun ortalamasının $(\bar{X}=14.93)$, kontrol grubunun ortalamasından $(\bar{X}=11.32)$ daha yüksek çıkması ve $p<.05$ olması deney grubu lehine anlamlı farklılık olduğunu göstermektedir.

\subsection{Onuncu Alt Probleme İlişsin Bulgular}

Araştırmanın onuncu alt problemi şu şekildedir:

"Deney ve kontrol grubundaki çocukların SBDÖ "Görevleri Tamamlama Becerileri" alt ölçeğinden aldıkları öntest puanları kontrol altına alındığında, sontest puanları arasında deney grubu lehine anlamlı bir fark var mıdır?"

Deney ve kontrol grubundaki çocukların SBDÖ "Görevleri Tamamlama Becerileri (GTB)" alt ölçeğinden elde edilen öntest - sontest puanlarının aritmetik ortalama, standart sapma değerleri ile kovaryans analizi sonucunda elde edilen düzeltilmiş sontest puan ortalamaları ile standart hata değerleri Tablo 26'da verilmiştir.

Tablo 26. Deney grubu ve kontrol grubundaki çocukların GTB'den elde edilen öntest- sontest puanlarının aritmetik ortalama, standart sapma, sontest düzeltilmiş puan ortalamaları ve standart hata değerleri

\begin{tabular}{|c|c|c|c|c|c|c|c|}
\hline \multirow{2}{*}{ Gruplar } & \multicolumn{4}{|c|}{ Toplam Puanlar } & \multirow{2}{*}{$\begin{array}{c}\text { Düzeltilmiş } \\
\text { Ortalamalar1 } \\
\overline{\boldsymbol{X}}_{\boldsymbol{d}}\end{array}$} & \multirow{2}{*}{$\begin{array}{c}\text { Sontest } \\
\text { Sh } \\
\end{array}$} & \multirow[t]{2}{*}{ Puan } \\
\hline & $\mathbf{N}$ & & $\bar{X}$ & SS & & & \\
\hline \multirow{2}{*}{$\begin{array}{l}\text { Deney } \\
\text { Grubu }\end{array}$} & \multirow{2}{*}{24} & Öntest & 10.46 & 2.21 & & & \\
\hline & & Sontest & 14.38 & 1.28 & 14.71 & .33 & \\
\hline \multirow{2}{*}{$\begin{array}{l}\text { Kontrol } \\
\text { Grubu }\end{array}$} & \multirow{2}{*}{24} & Öntest & 12.13 & 2.54 & & & \\
\hline & & Sontest & 13.08 & 2.22 & 12.75 & .33 & \\
\hline
\end{tabular}

Tablo 26'daki verilere bakıldığında hem deney grubunun hem kontrol grubunun GTB sontest puan ortalamalarının, öntest puan ortalamalarından yüksek olduğu görülmektedir. Deney grubunun ortalaması $(\bar{X}=14.71)$, kontrol grubu ortalamasına $(\bar{X}=12.75)$ göre daha yüksek çıkmıştır. İki grubun ortalamaları arasındaki bu farkın anlamlı olup olmadığını görmek için kovaryans analizi yapılmış, bulunan sonuçlar Tablo 27'de gösterilmiştir.

Tablo 27. Deney ve kontrol grubundaki çocukların GTB sontest puanlarının kovaryans analizi sonuçları

\begin{tabular}{|c|c|c|c|c|c|c|c|}
\hline Varyansın Kaynağı & $\begin{array}{l}\text { Kareler } \\
(\mathrm{KT})\end{array}$ & Toplamı & $\mathrm{Sd}$ & $\begin{array}{l}\text { Kareler } \\
(\mathrm{KO})\end{array}$ & Ortalamas1 & $\mathrm{F}$ & $\mathrm{P}$ \\
\hline $\begin{array}{l}\text { Kontrol Edilen } \\
\text { Değişken (Öntest) }\end{array}$ & 42.81 & & 1 & 42.81 & & 17.73 & .00 \\
\hline Gruplama Ana Etkisi & 41.17 & & 1 & 41.17 & & 17.05 & .00 \\
\hline Hata & 108.64 & & 45 & 2.41 & & & \\
\hline Toplam & 9219.00 & & 48 & & & & \\
\hline
\end{tabular}


Tablo 27'deki kovaryans analiz sonuçları incelendiğinde öntest puanları kontrol altına alındığında, grupların düzeltilmiş sontest puan ortalamaları bakımından drama temelli dijital hikâye anlatıcılı̆̆ programının anlamlı bir farklılık $(\mathrm{F}=17.05 ; \mathrm{p}=.00)$ oluşturduğu görülmüştür. Deney grubunun ortalamasının $(\bar{X}=14.71)$, kontrol grubunun ortalamasından $(\bar{X}=12.75)$ daha yüksek çıkması ve $\mathrm{p}<.05$ olması deney grubu lehine anlamlı farklılık olduğunu göstermektedir.

\section{Tartışma ve Sonuç}

$\mathrm{Bu}$ araştırmada drama temelli dijital hikâye anlatıcılığı programının altı yaş çocuklarının bazı sosyal becerilerine (kişiler arası beceriler, akran baskısı ile başa çıkma becerileri, sözel açılama becerileri vb.) etkisi incelenmiştir. Deney ve kontrol gruplarındaki çocuklara "Sosyal Becerileri Değerlendirme Ölçeği (SBDÖ)" öntest ve sontest olarak uygulanmıştır. Elde edilen verilerle kovaryans analizi yapılmış, öntest puanları kontrol altına alınarak deney ve kontrol gruplarının sontest puanları arasında anlamlı bir farklılık olup olmadığına bakılmıştır. SBDÖ toplam puanında, kızgınlık davranışlarını kontrol etme ve değişikliklere uyum sağlama becerileri, akran baskısı ile başa çıkma becerileri, sözel açılama becerileri, dinleme becerileri, amaç oluşturma becerileri, görevleri tamamlama becerileri alt boyutlarında deney grubu lehine anlamlı farklılık olduğu görülmüştür. Kişiler arası beceriler, kendini kontrol etme becerileri ve sonuçları kabul etme becerileri alt boyutlarında ise anlamlı farklılık oluşmadığı belirlenmiştir.

2000'li yıllarda sosyal becerilerle ilgili deneysel çalışmaların arttı̆̆ı görülmektedir. Alanyazında incelenen çalışmalarda sosyal becerileri geliştirmek için uygulanan çeşitli programların katılımcıların sosyal becerilerini olumlu yönde etkilediği görülmüştür (Denham, Hatfield, Smethurst, Tan ve Tribe, 2006; Kara ve Çam, 2007; Ekinci Vural ve Gürşimşek, 2009; Kaya ve Eratay, 2009; Eldeniz Çetin ve Avcıŏglu, 2010; Öziskender ve Güdek, 2013; Göktaş, 2015; Pekdoğan, 2016). Sosyal becerilerle ilgili çalışmaların artmasına rağmen dijital hikâye ve sosyal becerilerin birlikte yer aldığı çalışmaya pek rastlanmamaktadır. Dijital hikâye ile ilgili çalışmalar genelde lisans seviyesinde öğrencilerle yapılmış olup alt öğrenim kademelerinde yapılan çalışmalarda da çoğunlukla okuma veya yazma becerilerine etki araştırılmıştır. Bu nedenle bu araştırma, dijital hikâye ve sosyal becerilerle ilgili ulaşılan sonuçlarla okul öncesi dönemde verilecek eğitimin daha başarılı olmasında ve okul öncesinde dijital hikâye kullanımında yol gösterici olacaktır.

Yapılan araştırmada öntest puanları kontrol altına alındığında sontest puanları bakımından SBDÖ toplam puanının deney grubu lehine anlamlı farklılık oluşturması benzer araştırmalarca desteklenmektedir. Ekinci Vural ve Gürşimşek (2009)'in altı yaş çocuklarla yaptığ çalışmasında da deney grubu lehine anlamlı farklılık olduğu belirlenmiştir. Kaya ve Eratay (2009) tarafından yetişkin zihinsel engellilerle yapılan çalışmada yaratıcı dramanın sosyal becerilerin gelişiminde etkili olduğu sonucuna ulaşılmıştır. Eldeniz Çetin ve Avcıoğlu (2010) tarafından yapılan çalışmada ulaşılan bulguların araştırmayla tutarlı olduğu, yazarların dramayla hazırladıkları sosyal beceri öğretim programının öğrencilerde sosyal becerileri geliştirdiğini belirttikleri görülmüştür.

Yapılan araştırmada öntest puanları kontrol altına alındığında sontest puanları bakımından kişiler arası beceriler (KB) alt boyutundan elde edilen puanın deney grubu lehine anlamlı farklılık oluşturmadığ1 görülmüştür. Yurtseven ve Kurt (2013) tarafindan yapılmış çalışmada benzer sonuçlara ulaşılmış, çalışmasında aynı ölçeği (SBDÖ) uygulamış ve KB alt boyutunda anlamlı farklılık oluşmadığını görmüştür. Öğretmenlerin okul öncesi eğitimde işbirliğini 
artırmaya yönelik etkinlikler uygulaması kişiler arası becerilere etki ettiği ve bu nedenle iki grup arasında farklılık oluşmadığı belirtilebilir. Daha önce sadece ailesiyle veya sınırlı sayıda bireyle iletişim içinde olduğu düşünülen çocukların okul öncesi eğitime başlayınca sınıfta daha fazla bireyle iletişime girmeleri nedeniyle iki grupta da kişiler arası becerilerde benzer artış sağlanmış olabilir.

Yapılan araştırmada öntest puanları kontrol altına alındığında sontest puanları bakımından kızgınlık davranışlarını kontrol etme ve değişikliklere uyum sağlama becerileri alt boyutundan alınan puan deney grubu lehine anlamlı farklılık oluşturmuştur. Çocukların karşılaş̧ı̆̆ı her yeni durumun farklı koşullarına ve zorluklarına uyum sağlamak için çaba harcamaları gerekir (Yurtseven ve Kurt, 2013). Deney grubundaki etkinliklerde daha fazla yeni durumla karşılaşılması, etkinliklerde karşılaşılan farklı duyguların nasıl kontrol edilebileceğini akranlardan ve ögretmenlerden gözlemleme imkânı olması nedeniyle deney grubu lehine sonuç çıkmış olabilir.

Yapılan araştırmada öntest puanları kontrol altına alındığında sontest puanları bakımından akran baskısı ile başa çıkma becerileri alt boyutundan alınan puanın deney grubu lehine anlamlı farklılık oluşturması benzer araştırmalarca desteklenmektedir (Ekinci Vural ve Gürşimşek, 2009; Kaya ve Eratay, 2009; Eldeniz Çetin ve Avcıŏlu, 2010; Pekdoğan, 2016).

Yapılan araştırmada öntest puanları kontrol altına alındığında sontest puanları bakımından sözel açıklama becerileri alt boyutundan alınan puanın deney grubu lehine anlamlı farklılık oluşturması benzer araştırmalarca desteklenmektedir. Ekinci Vural ve Gürşimşek (2009)'in altı yaş çocuklarla yaptığı çalışmasında da deney grubu lehine anlamlı farklılık olduğu belirlenmiştir. Sadik tarafından 2008 yılında yapılan bir araştırmada, dijital hikâyeciliğin öğrencileri bilgilerini ve düşüncelerini ifade etmelerinde cesaretlendirdiği görülmüştür. Bunun yanında kişilere kendilerini daha rahat ifade edebilecekleri ortam sağladığı belirtilmiş̧tir (Ayvaz Tunç ve Karadağ, 2013). Abdolmanafi-Rokni ve Qarajeh (2014)'in geleneksel hikâye anlatıcılığı ve dijital hikâye anlatıcılığının konuşma becerisine etkisini inceledikleri çalışmada, dijital hikâye anlatıcılığı kullanılan deney grubu lehine sonuç çıkmıştır.

Yapılan araştırmada öntest puanları kontrol altına alındığında sontest puanları bakımından sonuçları kabul etme becerileri (SKEB) alt boyutundan ve kendini kontrol etme becerileri (KKEB) alt boyutundan elde edilen puanın deney grubu lehine anlamlı farklılık oluşturmadığ görülmüştür. Sontest puanlarına bakıldığında öntest puanlarına göre artış görülmekte ancak deney ve kontrol grupları arasında anlamlı farklılık görülmemektedir. Bu sonuç benzer araştırmalarca desteklenmektedir. Yurtseven ve Kurt (2013)'un yapmış olduğu çalışmada değişkenin sonuçları kabul etme becerileri üzerinde farklılık oluşturmadığını, okul öncesi eğitimin çocuklarda olumlu etki sağladığını belirtmişlerdir. Anlamlı farklılığın oluşmamasında deney ve kontrol grubunun okul öncesi eğitim alması gösterilebilir. Öziskender ve Güdek (2013) yapmış olduğu çalışmasında altı yaşındaki çocuklarla on haftalık deneysel sürecin başında ve sonunda SBDÖ uygulamış, SKEB ve KKEB alt boyutlarında anlamlı farklılık oluşmadığı sonucuna ulaşmıştır.

Yapılan araştırmada öntest puanları kontrol altına alındığında sontest puanları bakımından dinleme becerileri alt boyutundan alınan puanın deney grubu lehine anlamlı farklılik oluşturması benzer araştırmalarca desteklenmektedir. Ekinci Vural ve Gürşimşek (2009)'in altı yaş çocuklarla yaptığı çalışmasında da deney grubu lehine anlamlı farklılık olduğu belirlenmiştir. Pekdoğan (2016) beş - altı yaş çocuklarla yaptığı araştırmada hikâye temelli 
sosyal beceri eğitiminin sosyal becerilerin gelişimine etkisini incelemiş ve araştırmayla benzer sonuçlara ulaşmıştır. Collen (2007)'ın okul öncesi sınıflarda dijital hikâyelerin dinlediğini anlama üzerine etkilerini incelediği çalışmada hikâyeleri araştırmacıdan dinleyen çocukların dikkatli dinleyemediği ve sorulan sorulara cevap veremediği görülmüştür. Buna karşın dijital hikâye dinleyen deney grubundaki çocukların hikâyeyi daha dikkatli dinlediği, hikâye ile ilgili sorulan cevaplara doğru cevaplar verdikleri gözlemlenmiştir. Iubbad (2013)'ın yedinci sınıf öğrencileri üzerinde multimedyaya dayalı öğrenme programının İngilizce dersini dinleme becerisine ve dinlemeye yönelik tutumlarına etkisini araştırdığı çalışmasında deney grubu lehine anlamlı farklılık olduğu belirtilmiştir. Bu araştırmanın deneysel sürecinde de kullanılan etkinliklerin ilk uygulandığı zamanda öğrenciler birbirlerini dinlemede zorlanmış, aynı anda kendilerini ifade etmek istemişlerdir. Daha sonra etkinlikler yardımıyla öğrenciler akranlarına ve öğretmenlerine karşı daha duyarlı olmuş önce karşı tarafı dinleyerek problemlerini çözmeye, iletişim kurmaya dikkat etmişlerdir.

Yapılan araştırmada öntest puanları kontrol altına alındığında sontest puanları bakımından amaç oluşturma becerileri alt boyutundan ve görevleri tamamlama alt boyutundan alınan puanın deney grubu lehine anlamlı farklılık oluşturması benzer araştırmalarca desteklenmektedir (Yurtseven ve Kurt, 2013; Öziskender ve Güdek, 2013; Pekdoğan, 2016). Çocukların yaşlarına, yeteneklerine, ilgilerine uygun görev ve sorumluluk verilmesinin fayda sağladığı söylenebilir.

Araştırmanın sonuçları üzerinden bazı önerilerde bulunulabilir. Sosyal becerilere etki farklı değişkenler de eklenerek farklı örneklem gruplarıyla incelenebilir. Gelişen becerileri ilerleyen yıllarda da takip edip karşılaştırma yapmak için boylamsal inceleme yapılabilir.

Öğretmenlere sosyal becerileri geliştirmeye yönelik hizmet içi eğitimler verilebilir. Dijital hikâye ve drama ile ilgili bilgi eksikliğini gidermek ve önemini kavramak için öğretmenlerin daha lisans öğrenimini tamamlamadan çeşitli eğitimlere katılması sağlanabilir.

Araştırmada çocuklar sınıf̧̧a dijital hikâye hazırlamışlardır. Gerekli teknolojik donanımın bulunduğu bir ortamda bireysel veya grupla dijital hikâye hazırlamalarına imkân tanınabilir.

Araştırma deneysel bir çalışma olduğundan ölçekten elde edilen verilerle değerlendirme yapılmıştır. Dijital hikâye anlatıcılığına yönelik öğretmen, öğrenci ve veli görüşlerine başvurulan bir çalışma yapılabilir. 


\section{Kaynakça}

ABDOLMANAFİ-ROKNI, S.J., \& QARAJEH, M. (2014). Digital Storytelling in EFL Classrooms: The Effect on the Oral Performance. International Journal of Language and Linguistics, 2(4), 252-257.

AKAR, R. (2000). Temel Eğitimin İkinci Aşamasında Drama Yöntemi ile Türkçe Öğretimi: Dorothy Heathcote'un Uzman Rolü Yaklaşımı. Yüksek Lisans Tezi, Çukurova Üniversitesi Sosyal Bilimler Enstitüsü.

AKAR VURAL, R. (2005). Bertolt Brecht'in Öğretici Oyunlartnın "Eğitimde Drama" ve "Sahneleme" Yöntemleri Temelinde Hazırlanan İki Farkl Programın Ortaöğretim Hazırlık Sınıfi Öğrencilerinin Eleştirel Düşünmeye Yönelik Tutumlarına Etkisi. Yayınlanmamış Doktora Tezi, Çukurova Üniversitesi Sosyal Bilimler Enstitüsü.

AKAR VURAL, R. ve SOMERS, J. W. (2016). Hümanist İlköğretim Programları İçin Ilkögretimde Drama: Kuram ve Uygulama (3. b.). Ankara: Pegem Akademi.

AKCA, M. A., AYTAN, N. ve ÜNLÜ, S. (2016). Seslendirme Destekli Animasyonlaştırma Programının Geliştirilmesi Ve Hikâye Uygulaması. Uluslararası Sosyal Araştırmalar Dergisi, 9(42).

AKFIRAT ÖNALAN, F. (2006). Sosyal Yeterlilik, Sosyal Beceri ve Yaratıcı Drama. Yaratıcı Drama Dergisi, $1(1)$.

AVCIOĞLU, H. (2007). Sosyal Becerileri Değerlendirme Ölçeğinin Geçerlik Ve Güvenirlik Çalışması(4-6 Yaş). AİBÜ Eğitim Fakültesi Dergisi, 87-101.

AVCIOĞLU, H. (2012). Zihinsel Yetersizliği Olan Çocuklara Sosyal Beceri Kazandırmada İşbirliğine Dayalı Öğrenme ve Drama Yöntemlerinin Etkililiği. Eğitim ve Bilim, 37 (163), $110-125$.

AYVAZ TUNÇ, Ö. ve KARADAĞ, E. (2013). Postmodernden Oluşturmacilığa Dijital Öyküleme. Ĕgitim ve Öğretim Araştırmaları Dergisi, 2(4), 310-315.

BARRET, H.C. (2009). How to Create Simple Digital Stories. Retrieved April 28, 2017, from http://electronicportfolios.com/digistory/howto.html

BİLEK, M. H. (2011). Okul öncesi dönem çocuklarının ev ile okul ortamındaki sosyal becerilerinin karşılaştırılması. Yüksek Lisans Tezi, Trakya Üniversitesi Sosyal Bilimler Enstitüsü.

BÜYÜKÖZTÜRK, Ş. (2005). Sosyal Bilimler için Veri Analizi El Kitabı: İstatistik, Araştırma Deseni, SPSS Uygulamalart ve Yorum. Ankara: Pegem Akademi.

BÜYÜKÖZTÜRK, Ş., ÖMEROĞLU, E., AYDOĞAN, Y., ÇAKAN, M., ÖZYÜREK, A., GÜLTEKİN AKDUMAN, G., GÜNINDİ, Y., KUTLU, Ö., ÇOBAN, A., CEYLAN, Ş., ÖZAYDIN, L., SERT, N., YURT, Ö., KOĞAR, H., KARAYOL, S., CEYHUN, A. T., ATABEY, D. ve OĞUZ, T. (2014). Okul Öncesi Çocuklar İçin Sosyal Beceri Destek Ĕ̈itimi Öğretmen Rehber Kitabı (OSBEP). Ankara.

CEYLAN, Ş. (2009). Vineland Sosyal -Duygusal Erken Çocukluk Ölçeğinin GeçerlikGüvenirlik Çalışması ve Okul Öncesi Eğitim Kurumuna Devam Eden Beş Yaş Çocuklarının Sosyal - Duygusal Davranışlarına Yaratıcı Drama Eğitiminin Etkisinin İncelenmesi. Doktora Tezi, Gazi Üniversitesi Eğitim Bilimleri Enstitüsü. 
COLLEN, L. (2007). The Digital And Traditional Storytimes Research Project: Using Digitized Books For Preschool Group Storytimes. Retrieved June 9, 2017, from http://laurencollen.com/CAL_winter06_collen.pdf

ÇUBUKÇU, Z. ve GÜLTEKİN, M. (2006). İlköğretimde Öğrencilere Kazandırılması Gereken Sosyal Beceriler. Bilig - Türk Dünyası Sosyal Bilimler Dergisi, 37, 155-174.

EKINCİ VURAL, D. ve GÜRŞIMŞEK, I. (2009). Okul Öncesi Eğitimde Aile Katılımlı Sosyal Beceri Eğitimi. e-Journal of New World Sciences Academy, 4(3), 1110-1122.

ERBAY, E. (2008). Okul Öncesi Ë̆itim Alan ve Almayan Illkögretim Birinci Sinıf Ögrencilerinin Sosyal Becerilere Sahip Olma Düzeyleri. Yüksek Lisans Tezi, Pamukkale Üniversitesi Sosyal Bilimler Enstitüsü.

ELDENIZ ÇETIN, M. ve AVCIOĞLU, H. (2010). Zihin Engelli Öğrenciler İçin Drama Yöntemiyle Hazırlanan Sosyal Beceri Öğretim Programının Etkililiğinin İncelenmesi. International Online Journal of Educational Sciences, 2 (3), 792-817.

FIGA, E. (2004). The Virtualization of Stories and Storytelling. Storytelling Magazine, $16(2), 34-36$.

FLEWITT, R., MESSER, D. \& KUCIRKOVA, N. (2014). New Directions For Early Literacy İn A Digital Age: The iPad. Journal of Early Childhood Literacy, 15(3), 289-310.

GARCIA, P., \& ROSSITER, M. (2010). Digital storytelling as narrative pedagogy. Proceedings of society for information technology \& teacher education international conference, 1091-1097.

GÖKTAŞ, İ. (2015). Aile Katılımı ve Sosyal Beceri Eğitimi Programlarının Tek Başına ve Birlikte 4-5 Yaş Çocuklarının Sosyal Becerileri ve Anne-Çocuk İlişkileri Üzerindeki Etkisinin İncelenmesi. Yüksek Lisans Tezi, Pamukkale Üniversitesi Eğitim Bilimleri Enstitüsü.

HAGGERTY, M. (2011). Accessing Pedagogical Territories That Can't Be Put İnto Words: Using Video To Build Understandings Of Children's Multimodal Meaning-Making. Contemporary Issues in Early Childhood, 12(4), 385-398.

IUBBAD, S.H. (2013). The Effectiveness of A Multimedia Bassed Learning Program on Developing Seventh Graders' Listening Comprehension Skills and Attitudes in Gaza Governorate. Master thesis, The Islamic University, Gaza.

İNCEELLİ, A. (2005). Dijital Hikâye Anlatımının Bileşenleri. The Turkish Online Journal of Educational Technology, 4(3).

JAKES, D. S., \& BRENNAN, J. (2005). Capturing stories, capturing lives: An introduction to digital storytelling. Retrieved April 28, 2017, from http://www.jakesonline.org/dst_techforum.pdf

KARA, Y. ve ÇAM, F. (2007). Yaratıcı Drama Yönteminin Bazı Sosyal Becerilerin Kazandırılmasına Etkisi. Hacettepe Üniversitesi Eğitim Fakültesi Dergisi, 32, 145-155.

KARAKOYUN, F. (2014). Çevrimiçi Ortamda Oluşturulan Dijital Öyküleme Etkinliklerine İlişkin Öğretmen Adaylar Ve İlkögretim Öğrencilerinin Görüşlerinin İncelenmesi. Doktora Tezi, Anadolu Üniversitesi Eğitim Bilimleri Enstitüsü. 
KAYA, D. ve ERATAY (2009). Yetişkin Zihin Engelli Bireylerin Sosyal Becerilerinin Gelişiminde Yaratıcı Drama Yönteminin Etkililiğinin İncelenmesi. Yaratıcı Drama Dergisi, 4(8).

KERLINGER, F. N. (1973). Foundations of Behavioral Research (2.e). New York: Holt, Rinehart and Winston

KOTLUK, N. ve KOCAKAYA, S. (2015). 21.Yüzyıl Becerilerinin Gelişiminde Dijital Öykülemeler: Ortaöğretim Öğrencilerinin Görüşlerinin İncelenmesi. Ĕgitim ve Öğretim Araştırmaları Dergisi, 4(2), 354-363.

KÖKSAL AKYOL, A. (2003). Drama ve Dramanın Önemi. Türk Eğitim Bilimleri Dergisi, 2(1), 179-190.

LAMBERT, J. (2010). Digital Storytelling Cookbook. Digital Diner Press.

MCCASLIN, N. (2006). Creative Drama in the Classroom and Beyond (8. e.). New York: Longman.

ÖZİSKENDER, G. ve GÜDEK, B. (2013). Orff Yaklaşımı İle Yapılan Okul Öncesi Müzik Eğitiminin Öğrencilerin Sosyal Becerilerinin Gelişimine Etkileri. Turkish Studies, 8(3), 213-232.

ÖZYÜREK, A. ve CEYLAN, Ş. (2014). Okul Öncesi Çocuklarda Sosyal Becerilerin Desteklenmesi Konusunda Öğretmen ve Veli Görüşlerinin Belirlenmesi. Pamukkale Üniversitesi Eğitim Fakültesi Dergisi, 99-114.

PEKDOĞAN, S. (2016). Hikâye Temelli Sosyal Beceri Eğitim Programının 5-6 Yaş Çocukların Sosyal Becerilerinin Gelişimine Etkisinin İncelenmesi. Eğitim ve Bilim, 41(183), 305-318.

ROBIN, B. R. (2006). The Educational Uses of Digital Storytelling. Retrieved April 23, 2017, from http://digitalstorytelling.coe.uh.edu/articles/Educ-Uses-DS.pdf

ROBIN, B. R. (2008). Digital storytelling: a powerful technology tool for the 21 st century classroom. Theory Into Practice, 47(3), 220-228.

SADIK, A. (2008). Digital storytelling: a meaningful technology-integrated approach for engaged student learning. Educational Technology Research and Development, 56(4), 487-506.

SAĞLAM, T. (2014). Dramatik Eğitim: Amaç mı? Araç mı? Dramatic Education: Aim or Medium?. Tiyatro Araştırmaları Dergisi, 17.

TATLI, Z. H. (2016). Dijital Öyküleme. A. İşman, H. F. Odabaşı, ve B. Akkoyunlu, (Ed.), Eğitim Teknolojileri Okumaları içinde (s. 219-233). Ankara.

TUĞLUK, İ. H., KÖK, M., KOÇYİĞİT, S., KAYA, H. İ. ve GENÇDOĞAN, B. (2008). Okul Öncesi Öğretmenlerinin Okuma - Yazma Etkinliklerini Uygulamaya İlişkin Görüşlerinin Değerlendirilmesi. Kazım Karabekir Eğitim Fakültesi Dergisi, 17.

TURGUT, G. ve KIŞLA, T. (2015). Bilgisayar destekli hikâye anlatımı yöntemi: Alanyazın araştırmas1. Turkish Online Journal of Qualitative Inquiry, 6(2), 97-121.

ULUTAŞ, A. (2011). Okul Öncesi Dönemde Drama Ve Oyunun Önemi. Adıyaman Üniversitesi Sosyal Bilimler Enstitüsü Dergisi, 4(6), 233-242. 
WANG, S. \& ZHAN, H. (2010). Enhancing Teaching and Learning with Digital Storytelling. International Journal of Information and Communication Technology Education.

XU, Y., PARK, H., \& BAEK, Y. (2011). A New Approach Toward Digital Storytelling: An Activity Focused on Writing Selfefficacy in a Virtual Learning Environment. Educational Technology \& Society, 14 (4), 181-191.

YANG, Y. T. C. \& WU, W. C. I. (2012). Digital Storytelling for Enhancing Student Academic Achievement, Critical Thinking, And Learning Motivation: A year-long experimental study. Computers \& Education, 59(2), 339-352.

YURTSEVEN, L. ve KURT, G. (2013). Okul Öncesi Eğitiminin ve Annelerin Hikâye Kitabı Okumasının Çocukların Sosyal Beceri Gelişimi ile İlişkisi. CÜ Sosyal Bilimler Dergisi, $37(2)$.

YÜZER, T. V. ve KILINÇ, H. (2015). Açık Öğrenme Sistemlerinde Dijital Öykülemeden Faydalanmak. Eğitim ve Öğretim Araştırmaları Dergisi, 4(1), 243-250. 